\title{
Detecting snow-related signals in radial growth of Pinus uncinata mountain forests
}

Alba Sanmiguel-Vallelado ${ }^{1}$, J. Julio Camarero ${ }^{1}$, Antonio Gazol ${ }^{1}$, Enrique MoránTejeda $^{2}$, Gabriel Sangüesa-Barreda ${ }^{3,1}$, Esteban Alonso-González ${ }^{1}$, Emilia Gutiérrez ${ }^{4}$, Arben Q. Alla ${ }^{5}$, J. Diego Galván ${ }^{6}$, Juan Ignacio López-Moreno ${ }^{1}$.

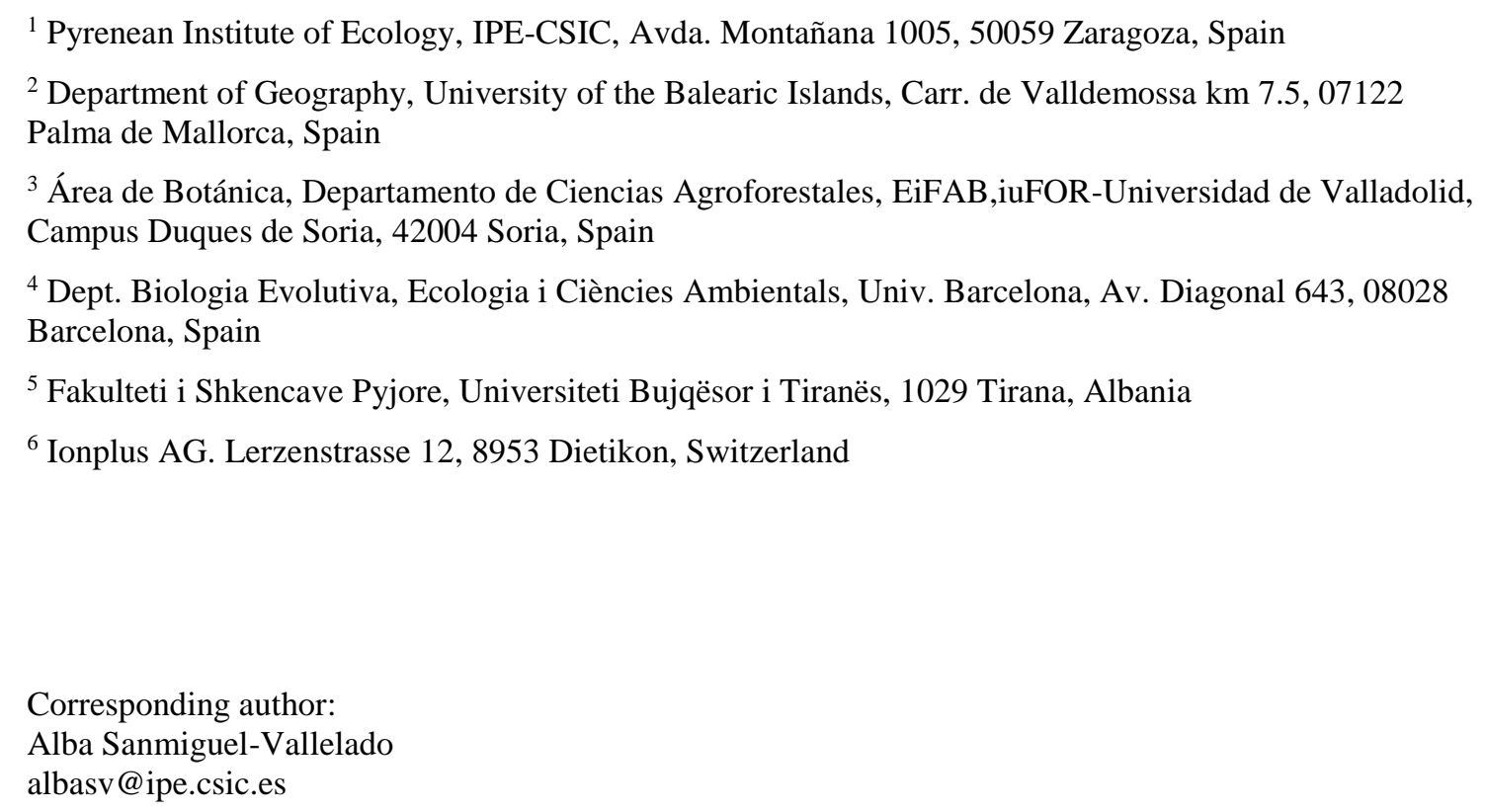


Abstract

Climate warming is responsible for observed reduction in snowpack depth and an earlier and faster melt-out in many mountains of the Northern Hemisphere. Such changes in mountain hydroclimate could negatively affect productivity and tree growth in highelevation forests, but few studies have investigated how and where recent warming trends and changes in snow cover influence forest growth. A network comprising 36 highelevation Pinus uncinata forests was sampled in the NE Iberian Peninsula, mainly across the Spanish Pyrenees, using dendrochronology to relate tree radial growth to a detailed air temperature and snow depth data. Radial growth was negatively influenced by a longer winter snow season and a higher late-spring snowpack depth. Notably, the effect of snow on tree growth was found regardless the widely reported positive effect of growing-season air temperatures on $P$. uncinata growth. No positive influence of moisture from spring snowmelt on annual growth of $P$. uncinata was detected in sampled forests. Tall trees showed a lower growth responsiveness to snow than small trees. Decreasing trends in winter and spring snow depths were detected at most Pyrenean forests, suggesting that the growth of high-elevation P. uncinata forests can beneficiate for a shallower and of shorter duration snowpack associated with warmer conditions. However, water-limited sites located on steep slopes or on rocky substrates, with poor soil-water holding capacity, could experience drought stress because of early depleted snow-related soil moisture.

Keywords: dendroecology, tree-ring width, snowpack, subalpine forests, Pyrenees. 


\section{Introduction}

54 Mountain forests are particularly susceptible to climatic variation because low temperatures typically limit radial growth and productivity near the uppermost edge of tree distribution ranges (Körner, 2012). Recent warming trends have induced shifts in tree recruitment (Smithers et al., 2018; Sangüesa-Barreda et al., 2018) and have enhanced radial growth (Innes, 1991; Tardif et al., 2003; Camarero et al., 2015a; Zhuang et al., 2017), excepting few sites were warming have induced some drought stress (Camarero et al., 2015c, Galván et al. 2015). Most studies have focused on the direct effects of rising temperatures on tree growth (e.g. Del Barrio et al., 1990; Gutierrez et al., 1991; Tardif et al., 2003; Andreu et al., 2007; Galván et al., 2014; Camarero et al., 2017; Franke et al., 2017; D’Orangeville et al., 2018; Sanchez-Salguero et al., 2018; Wang et al., 2019). Research focused on the indirect effects of climate warming, such as the influence of snow dynamics on forest productivity, is still scarce (Vaganov et al., 1999; Kirdyanov et al., 2003, Helama et al., 2013, Watson and Luckman 2016; Carlson et al., 2017).

Snow accumulation requires a combination of precipitation and low temperatures to initiate snowfall and persistent below-zero temperatures to sustain the snowpack (Beniston et al., 2011; López-Moreno et al., 2011). Due to the high sensitivity of snow cover to seasonal temperatures (Morán-Tejeda et al., 2013a), a warmer climate can easily impact the process of snow accumulation/melting (Beniston, 2003). An increase in winter temperature leads to a precipitation shift from snow towards rain, and warmer spring conditions induce earlier and faster snowpack melting (Morán-Tejeda et al., 2014). Reduced snowpack depth and duration have been reported in the main mid-latitude mountain ranges (López-Moreno, 2005; Marty, 2008; McCabe and Wolock, 2009; Beniston, 2012; Morán-Tejeda et al., 2013a) including Mediterranean (drought-prone) areas such as the Pyrenees (Morán-Tejeda et al., 2017). 
Snow dynamics may influence forest growth (e.g., Kirdyanov et al., 2003). Early snowfalls in the autumn may shorten the growing season and lead to a reduction in the assimilation of carbohydrates, and this can negatively affect growth in the following year (Carlson et al., 2017). A lack of snow cover during the winter can cause premature yellowing and shedding of needles of shrubby krummholz individuals during cold and dry winters and repeated freeze-thaw cycles (winter drought), reducing growth in the following spring (Helama et al., 2013; Camarero et al. 2015b). Larger snow accumulation and a longer snowmelt period may negatively affect tree radial growth by slowing the increase of soil temperature, delaying the growing period, and thus shortening the growing season (Vaganov et al., 1999; Kirdyanov et al., 2003; Watson and Luckman, 2016). On the other hand, snowmelt effects on soil moisture have been reported to positively influence tree growth during the next growing season (St. George, 2014; Watson and Luckman, 2016). All these observations suggest that the radial growth of trees can be related to winter snowpack, melt-out date and spring snow depth.

In the main mountains of the NE Iberian Peninsula (Pyrenees, Pre-Pyrenees, Iberian System), increasing trends in mean temperatures and an increment in precipitation variability have been observed during the second half of the 20th century (López-Moreno et al., 2010; El Kenawy et al., 2011). Such consequent water stress increase may also limit tree growth in high-elevation forests (Tardif et al., 2003; Andreu et al., 2007). Nevertheless, high-elevation mountain pine (Pinus uncinata) forests and treelines are forecasted to show enhanced growth during the late $21^{\text {st }}$ century due to a longer and warmer growing season (Sánchez-Salguero et al., 2012, Camarero et al., 2017). Climate warming has also affected mountain hydrology and influences the accumulation, duration and melt-out of snow, leading to a shallow snowpack or a longer snow-free season (Morán-Tejeda et al., 2013a, 2013b). Discerning how and where snow dynamics affects 
forest growth may help us understand future responses of mountain forests to forecasted hydroclimatic change.

The main hypothesis of the present study is that snowpack depth and duration influence radial growth of high-elevation $P$. uncinata forests. It was expected that snow cover affects tree radial growth, in addition to the widely reported temperature effects on growth (Gutiérrez, 1991; Rolland and Schueller, 1994; Camarero et al., 1998). It was also expected that there would be greater impact of snowpack depth and duration on growth in high-elevation forests with a shorter growing season, since elevation indirectly controls the effects of climate on $P$. uncinata growth by modifying growing season air temperature (Tardif et al., 2003; Galván et al., 2014). These hypotheses were tested by analyzing the radial growth of a $P$. uncinata dendrochronological network in the main mountain ranges of NE Iberia in relation to snow cover conditions at site level. The specific objectives of the present study were: (1) to evaluate the associations between snow conditions and radial-growth variability of $P$. uncinata forests; (2) to explore the influence of biogeographical patterns and tree characteristics on tree growth responses to snow depth; and (3) to estimate and compare the temporal evolution of radial growth and snow trends for the 1980-2010 period.

\section{Materials and methods}

\subsection{Study species}

The mountain pine (Pinus uncinata Ram.) is a long-lasting and light-demanding conifer, which shows a wide ecological tolerance regarding topography (slope, aspect, elevation) and soil type (Cantegrel, 1983) and forms high-elevation forests. The natural habitat of P. uncinata includes central and southwest European mountains, while its southern geographical limit is reached in the Iberian System (Spain). It is dominant in the subalpine 
belt of the central and eastern Pyrenees (1800-2500 m a.s.l.). Its growing season starts at the end of May and ends in October, with major growth rates occurring from the end of May to July (Camarero et al., 1998). Warm autumn and spring temperatures before and during tree-ring formation enhance $P$. uncinata radial growth, whereas summer precipitation during the growing season is the main positive climate driver of growth in certain xeric sites located in the Pre-Pyrenees and southern Iberian System (Gutiérrez, 1991; Camarero et al., 1998; Tardif et al., 2003; Andreu et al., 2007; Galván et al., 2014). The timing of $P$. uncinata tree-ring formation is schematized in Figure 1.

\subsection{Study sites}

The 36 studied forests are located in the main mountain ranges of the NE Iberian Peninsula (Figure 2): 33 are located in the Pyrenees, (3 of them in the Pre-Pyrenees, the Pyrenees' foothills), and the other 3 sites are located in the Iberian System. Two of the sites sampled in the southern Iberian system (VATE, VA1U) constitute the southernmost distribution limit of the species in Europe. Sampled sites cover the whole geographical distribution of the species in the Iberian Peninsula. The elevation of the sampled sites ranges from 1750 to $2451 \mathrm{~m}$ a.s.l. and the mean slope of the terrain is $35^{\circ} \pm 16^{\circ}$ (see Table $\mathrm{S} 1$ in the Supplementary Material). Mean diameter at breast height (dbh) measured at 1.3 $\mathrm{m}$ of sampled trees is $66 \pm 7 \mathrm{~cm}$, and their age is $334 \pm 108$ years on average (Table $\mathrm{S} 1$ ).

The location of the Pyrenees, between the Atlantic Ocean on the west side and the Mediterranean Sea in the east, causes a fast climatic transition, while the Central Pyrenees shows a greater continental influence (Del Barrio et al., 1990). In the western areas, most of the annual precipitation falls during the cold winter season, whereas precipitation falls mainly during spring and autumn in the east (Del Barrio et al., 1990). Air temperature changes depend on elevation with $-5.17^{\circ} \mathrm{C} \mathrm{km}^{-1}$ being the mean temperature lapse rate 
across the Pyrenees (Navarro-Serrano et al. 2018). The annual $0{ }^{\circ} \mathrm{C}$ isotherm is located at 2900 m a.s.l. (Del Barrio et al., 1990), whereas it falls to $1600 \mathrm{~m}$ a.s.l. between December and April, establishing the lower limit of the seasonal snowpack (López-Moreno et al., 2011). Snow accumulation also shows a correlation to Atlantic-Mediterranean proximity and distance from the main divide of the mountain range (Revuelto et al., 2012). Monthly mean values of temperature, snow depth and melt-out date from1980 to 2009 hydrological years for all sampled sites are presented in Figure 1.
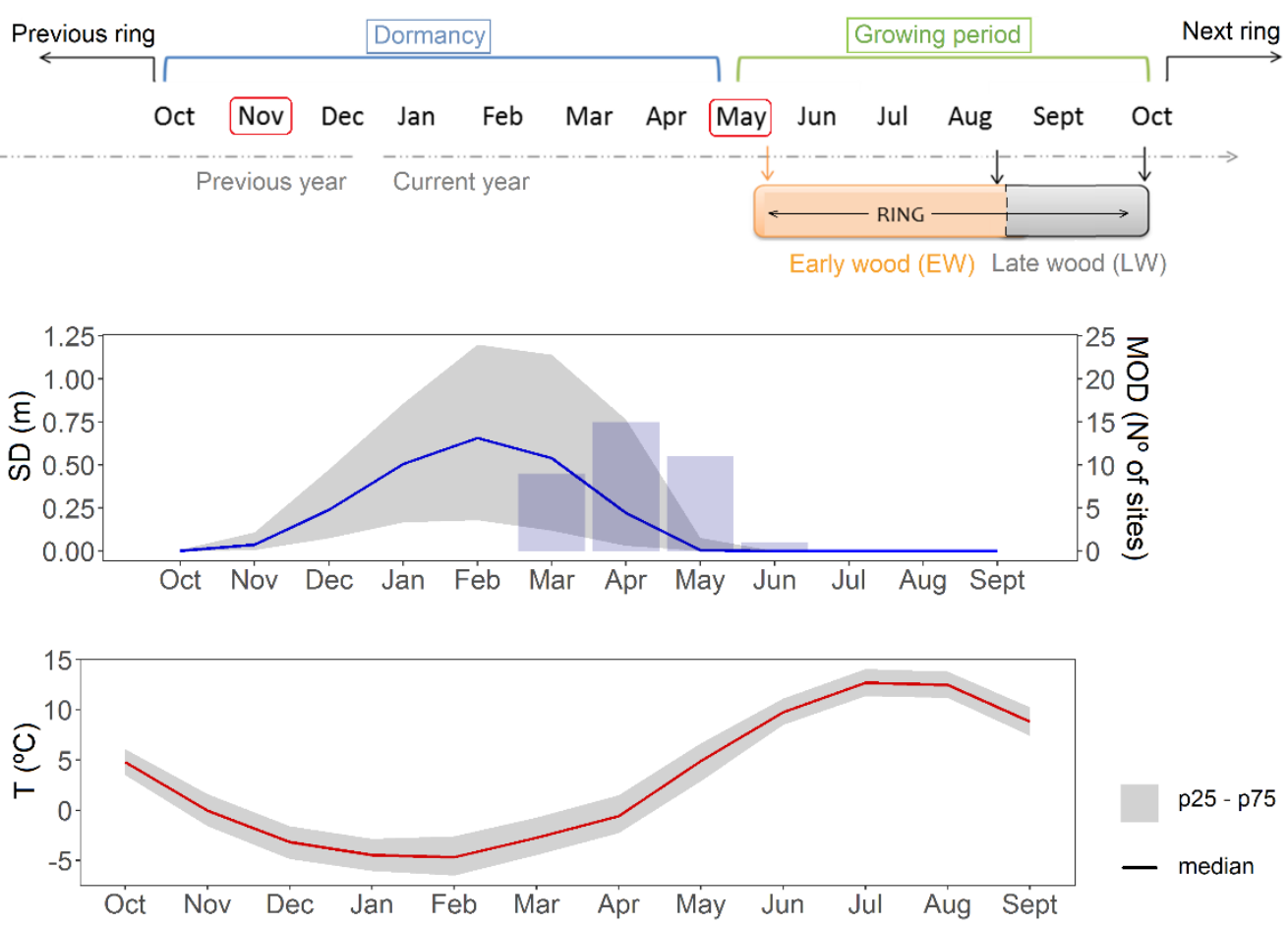

161

Figure 1. Top panel: Timing of $P$. uncinata tree-ring formation based on Camarero et al. (1998). Red boxes indicate the most influencing months to $P$. uncinata radial growth by temperature (Tardif et al., 2003; Galván et al., 2014). Bottom panels: monthly median snow depth (SD, blue line), melt-out date frequency (MOD, bars) and monthly median temperature (T, red line) of sampled sites in NE Iberian Peninsula from 1980 to 2009 hydrological years. Shaded areas show the 25-75 percentile ranks. 


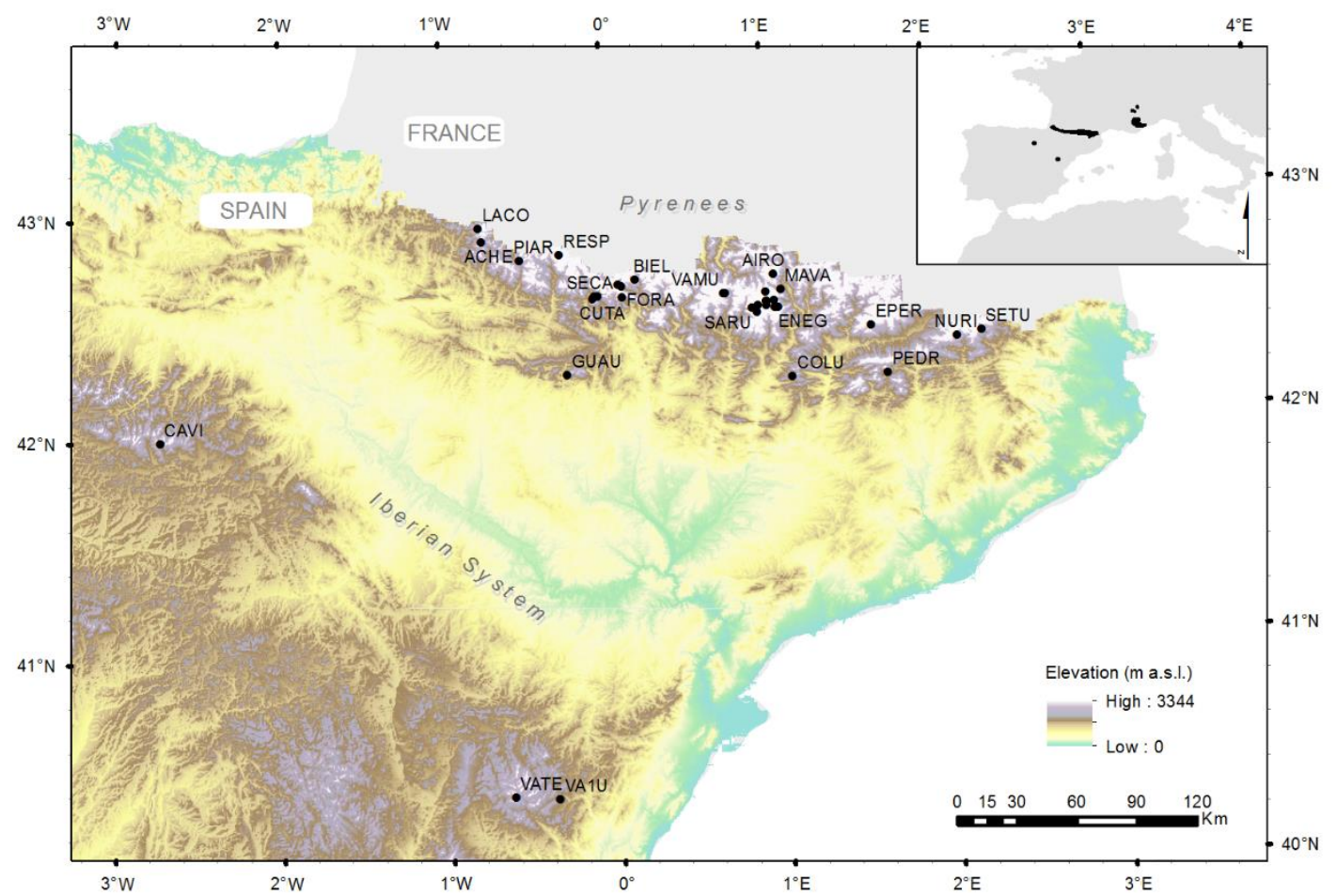

Figure 2. Map of sampled mountain $P$. uncinata sites in NE Iberian Peninsula (black dots, see sites' codes in Table S1) and distribution of the study species in Europe (inset, top right).

\subsection{Dendrochronological data}

Dendrochronological data correspond to an updating of data from 36 forests sampled and published by Galván et al. (2012, 2014). Wood samples were collected between 1994 and 2010 from 5 to 65 dominant individual trees of different sizes and ages, randomly selected in each site. From each tree, two or three cores were taken at $1.3 \mathrm{~m}$ height with Pressler increment borers. The sapwood length was measured in the field, and topographic (elevation, slope and aspect) and biometric (dbh and tree height) variables were also recorded for each individual tree.

Wood samples were air dried and sanded until tree-ring boundaries were clearly visible. Then, they were visually cross-dated and measured at $0.01 \mathrm{~mm}$ resolution using a LINTAB measuring device (Rinntech, Heidelberg, Germany). Cross-dating quality was checked using the program COFECHA (Holmes, 1983) by comparing the individual ring- 
width series among coexisting trees of the same species. Finally, cross-dated tree-ring width (RWL) series were obtained.

Dimensionless ring-width indices (RWI) series were obtained by removing age or size trends and temporal autocorrelation to reflect growth response to climate. Residual RWIs were obtained by removing long-term trends of ring-width data fitting negative linear functions, followed by 30 -year cubic smoothing splines, and then by eliminating the first-order autocorrelation of the resulting residuals using the software ARSTAN V. 44 (Cook, 1985). A bi-weight robust mean was then computed to obtain residual or prewhitened chronologies (mean site series) for each site, which were used in subsequent analyses.

\subsection{Climatic and snow data}

Daily snow depth (SD) and temperature data (T) for the studied sites were extracted from a gridded meteorological dataset obtained by simulation from Weather Research and Forecasting (WRF; Skamarock et al., 2008) model. The WRF model was driven by ERAInterim (Berrisford et al., 2011) reanalysis and coupled offline with Factorial Snow Model (FSM 1.0; Essery, 2015), a physically based energy and mass balance snow model. WRF outputs were projected to the target elevation, using hygrobarometric formulas and lapse rates and the new projected meteorological information as driving data of FSM. The methodology to develop the snow dataset and its validation is shown in Alonso-González et al. (2018).

Several annual snow indices were created from the daily snow data as indicators of specific snow conditions all year round, based on Figure 1:

- Average November snow depth (Nov SD) as previous autumn snow conditions indicator.

- Average February snow depth (Feb SD) as winter snow conditions indicator. 
- Average May snow depth (May SD) as spring snow conditions indicator.

The selection of these monthly SD values for representing snow seasonal conditions is based on the cumulative nature of snow. Thus, the snow depth value at the end of the season will be representative of the accumulated snow and the meteorological conditions of the previous months (e.g. López-Moreno et al., 2005; Morán-Tejeda et al., 2016). Snow indices were not highly correlated with each other, showing an average coefficient of correlation lower than $r_{s}=0.55$ (Spearman Rho). Variables were detrended prior to the correlation analyses. Correlation coefficients $\left(r_{s}\right)$ were: 0.48 for Nov SD - Feb SD, 0.33 for Nov SD - May SD and 0.54 for Feb SD - May SD.

Given that snow depth conditions of a given month are highly influenced by the temperature of previous months, the following monthly aggregations (averages) of temperature data were computed for statistical analyses: November mean temperature (Nov T), February mean temperature (Feb T), November-December-January-February mean temperature (Nov-Feb T), December-January-February mean temperature (DecFeb T), January-February mean temperature (Jan-Feb T), May mean temperature (May T), March-April-May mean temperature (Mar-May T), April-May mean temperature (Apr-May T).

\subsection{Statistical analyses}

We searched for snowpack effects on subsequent tree-ring development, considering the period from November (previous to tree-ring formation) to May, based on snow cover presence at the sampled forests (Figure 1).

The growing-season air temperature is a major and widely reported determinant of P. uncinata growth (Gutiérrez, 1991; Rolland and Schueller, 1994; Camarero et al., 1998; Tardif et al., 2003; Andreu et al., 2007; Galván et al., 2014). However, temperature also 
determines the large variability of snowpack among elevations (López-Moreno, 2005; Morán-Tejeda et al., 2013b). Because the aim was to control the temperature effect on growth (RWI) and infer the pure effect of snow, the computed snow indices from the influence of temperature were isolated. This was done by considering the aforementioned snow depth and temperature indices as predictors of RWI by means of stepwise linear regressions. First, Spearman non-parametric correlations $\left(r_{s}\right)$ were computed between the snow depth indices (Nov SD, Feb SD, May SD) and the whole set of temperature monthly aggregations. Temperature aggregations that best correlated with snow indices were November T, Jan-Feb T and Mar-May T for Nov SD, Feb SD and May SD (See Supplementary Material Table S2). These best-correlated temperature aggregations, together with mean May temperature, because its influence on tree growth is widely reported as the most important (e.g., Tardif et al. 2003) and the snow depth indices were then used as predictors in the stepwise linear models (Eq. 1). The stepwise model allows introduction of variables that substantially improve the model by rejecting those that may be redundant. This prevents greatly auto-correlated variables from being included in the model and allowed us to infer whether the snow depth indices or temperature indices were the best predictors of RWI. Linear models were performed individually for each site, as well as a regional model for the whole set of sites. The models can be formulated as follows:

$$
y=\beta_{0}+\beta_{1} x_{1}+\beta_{2} x_{2}+\cdots+\beta_{\mathrm{n}} x_{n}+\varepsilon
$$

where $y$ is the response variable (i.e. RWI values), $\beta_{0}$ is the intercept, $x_{1}$ to $x_{n}$ are the predictors (i.e., snow depth and temperature indices), $\beta_{1}$ to $\beta_{\mathrm{n}}$ are the estimated partial regression coefficients and $\varepsilon$ is the error. The models were compared using the Akaike Information Criterion (AIC) value; the smaller the AIC, the better the fit (most parsimonious model) since it penalizes complex models (Burnham and Anderson, 2003). 
Only the best model for each site and the one run for the whole set of sites are shown in the results, including the following information: the explained variance (adjusted $\mathrm{R}^{2}$ ), the statistical significance (p) and the partial coefficients of the regressions. Automated model selection was performed with the MuMIn package (Barton and Barton, 2018) of the R language version 3.1.0 (R Core Team, 2014).

Additionally, partial correlations using the Spearman coefficient were calculated between RWI and SD indices by partially removing the effects of temperature (Table S2). Non-parametric methods were used, since not all analyzed variables had normal distributions (Shapiro-Wilk test, $\mathrm{p}<0.05$ ). Snow and temperature variables were previously detrended.

Variations of tree growth responses to snow conditions along biogeographical gradients for a subset of sites where a snow index was the best predictor in the aforementioned stepwise models were investigated. The following variables were considered: latitude, longitude, slope, elevation of the terrain, dbh, tree height, sapwood and tree age (Table S1), and annual maximum snow depth (Max SD) (as an indicator of site differences in snow accumulation). Statistically significant different responses among groups of sites whose models selected the same best predictor using the non-parametric Kruskal-Wallis test were identified along gradients. Non-parametric Spearman correlations were calculated, considering the amount of radial growth variance explained by snow variables (adjusted $\mathrm{R}^{2}$ from the stepwise models) as the dependent variable and biogeographical gradients as independent variables. Complementary correlation analyses were done using partial correlation coefficients between tree growth and snow depth as dependent variables (in Supplementary Material Figure S3).

Trend analysis for tree-ring width (RWL series) as well as for snow indices was performed using the Mann-Kendall test and Theil-Sen's slope estimator for computing 
the magnitude of the trend, considering a subset of sites where any snow - growth significant relationship was previously found. Trend analysis was carried out using the zyp package in R language (Bronaugh et al., 2009), which includes a trend-free prewhitening method for removing serial autocorrelation.

RWI and RWL series were shorter than the snow series at some sites. Thus, all analyses were performed for the longest common period available, for example, from 1981 to last formed tree-ring measured (number of available years for each one is indicated in Table S1).

\section{Results}

\subsection{Growth responses to snow variables}

Stepwise linear models (Table 1) pointed out snow indices as main predictors of $P$. uncinata radial growth in $47 \%$ of sites (17 out of 36 sites; with 11 out of the 17 showing a statistically significant model). These 17 sites (Figure 3) were selected and used in later analyses. Average explained variance by models in these sites was $24 \%$ (30\% for statistically significant models). The site in which predictors explained the larger variance of RWI was CONU (adjusted $\mathrm{R}^{2}=0.81$; Table 1). May SD was the best predictor in $64 \%$ of sites where snow indices were the most important predictors and their models were statistically significant (Figure 4). It was followed by Feb SD (selected in 27\% of these sites) and Nov SD (only selected in one of these 11 sites). All snow indices negatively influenced radial growth (RWI) in all sites, except for Nov SD, which positively influenced tree radial growth in VA1U site.

In total, $17 \%$ of statistically significant models (6 out of 36 sites) pointed out temperature indices as main predictors of $P$. uncinata radial growth. Jan-Feb $\mathrm{T}$ was 
310 selected as the best predictor of RWI in 5 out of 6 of these sites, and Mar-May T was selected in only one site.

For the regional model, which takes into account all of the 36 site-chronologies combined (Table 1, bottom), Nov SD was selected as the most important predictor 314 (despite it only explained $5 \%$ of the total variance). When a subset of statistically predictor again explaining $13 \%$ of the total growth variance. prevalence of Feb SD, with respect to the other two snow indices, in terms of influencing radial growth of $P$. uncinata (Table S3 and Figure S1, Supplementary Material). Most sites $(67 \%)$ showed a Feb SD negative influence on radial growth (mean $r_{s}=-0.34$; SD = 0.18), being five of them statistically significant. For May SD, one site showed statistically significant partial correlation with radial growth.

Table 1. Statistical parameters of stepwise linear models between radial growth (response variable RWI) and snow and temperature indices (predictors) in each site, for all sites (All sites), and for all statistically significant sites (Sig sites). See sites codes in Table S1 and Figure 2.

\begin{tabular}{|c|c|c|c|c|c|c|c|c|c|c|c|}
\hline \multirow{2}{*}{ Site } & \multirow{2}{*}{$\mathrm{N}$} & \multicolumn{8}{|c|}{ Coefficients } & \multirow{2}{*}{$\begin{array}{c}\text { Adjusted } \\
\mathrm{R}^{2} \\
\end{array}$} & \multirow{2}{*}{$\mathrm{p}$} \\
\hline & & Intercept & Nov SD & Feb SD & May SD & Nov $T$ & May $\mathrm{T}$ & Jan-Feb T & Mar-May T & & \\
\hline ACHE* & 30 & 0.99 & & & -0.15 & & & & & 0.11 & 0.041 \\
\hline AIRO* & 16 & 1.00 & & & -0.16 & & & 0.04 & & 0.50 & 0.019 \\
\hline BIEL* & 16 & 1.01 & & & -4.30 & & & & & 0.20 & 0.046 \\
\hline BLLA & 30 & 0.99 & & & & & 0.03 & 0.03 & & 0.25 & 0.098 \\
\hline CAVI & 30 & 1.01 & -0.36 & -0.07 & & 0.02 & & & & 0.16 & 0.090 \\
\hline COLU & 30 & & & & & & & & & - & \\
\hline CONU* & 14 & 0.99 & -0.77 & -0.11 & -0.56 & & & & -0.08 & 0.81 & 0.001 \\
\hline CORT & 30 & 1.00 & & & -1.80 & & & & & 0.08 & 0.072 \\
\hline CUTA & 17 & 1.00 & & & & -0.03 & & & & 0.17 & 0.058 \\
\hline EAMI* & 29 & 1.00 & & & -0.55 & & & & & 0.23 & 0.005 \\
\hline EGER* & 30 & 0.99 & & & -0.17 & & & 0.02 & & 0.21 & 0.019 \\
\hline ELLA & 29 & & & & & & & & & - & \\
\hline ENEG* & 29 & 0.99 & & & -0.32 & -0.02 & & & & 0.26 & 0.006 \\
\hline EPER* & 17 & 0.99 & & & & & & 0.07 & & 0.44 & 0.002 \\
\hline FORA & 29 & & & & & & & & & - & \\
\hline GUAU & 30 & & & & & & & & & - & \\
\hline LACO & 19 & & & & & & & & & - & \\
\hline LEST & 13 & 1.00 & & -0.29 & & & & & & 0.18 & 0.084 \\
\hline
\end{tabular}




\begin{tabular}{|c|c|c|c|c|c|c|c|c|c|c|c|}
\hline MAVA* & 17 & 1.00 & & & & & & 0.09 & & 0.29 & 0.016 \\
\hline MIRA & 29 & 1.00 & & & & & & & 0.05 & 0.10 & 0.055 \\
\hline MIRE* & 18 & 0.99 & & -0.18 & & & & & & 0.19 & 0.041 \\
\hline MONE & 29 & 1.00 & & -0.08 & -1.36 & & & & & 0.19 & 0.082 \\
\hline NURI* & 21 & 0.99 & & & & -0.03 & & 0.05 & & 0.42 & 0.005 \\
\hline PEDR & 26 & 1.00 & & & & & & 0.03 & & 0.10 & 0.063 \\
\hline PIAR & 14 & 1.01 & & & & & & 0.04 & & 0.21 & 0.059 \\
\hline RATE & 29 & 0.99 & 0.76 & & & & & & & 0.06 & 0.109 \\
\hline RESP & 30 & 1.00 & & & -0.04 & & & & & 0.08 & 0.071 \\
\hline SAMA* & 16 & 0.98 & & & & & & 0.08 & & 0.20 & 0.047 \\
\hline SARU* & 15 & 1.00 & & -0.27 & & & & & & 0.25 & 0.034 \\
\hline SECA & 29 & & & & & & & & & - & \\
\hline SETU & 19 & & & & & & & & & - & \\
\hline SOBR & 29 & & & & & & & & & - & \\
\hline TESO* & 15 & 0.97 & & & & & & 0.08 & & 0.28 & 0.024 \\
\hline VA1U* & 26 & 1.00 & 1.77 & & -2.83 & & & & & 0.17 & 0.030 \\
\hline VAMU* & 14 & 1.02 & & -0.23 & & & & & & 0.35 & 0.015 \\
\hline VATE* & 26 & 0.99 & & & & & & & 0.08 & 0.15 & 0.028 \\
\hline All sites & - & 0.99 & 0.08 & & -0.03 & -0.01 & 0.01 & 0.01 & -0.01 & 0.05 & 0.00 \\
\hline Sig sites & - & 0.99 & & & -0.13 & -0.01 & 0.02 & 0.01 & -0.01 & 0.13 & 0.00 \\
\hline
\end{tabular}

329 N: data series length starting from 1981 (years). Statistically significant sites (model $p<$ 3300.05 ) are followed by $*$. The best predictor for each model (site) is indicated in bold 331 characters. Hyphen indicates null models (any significant predictor).

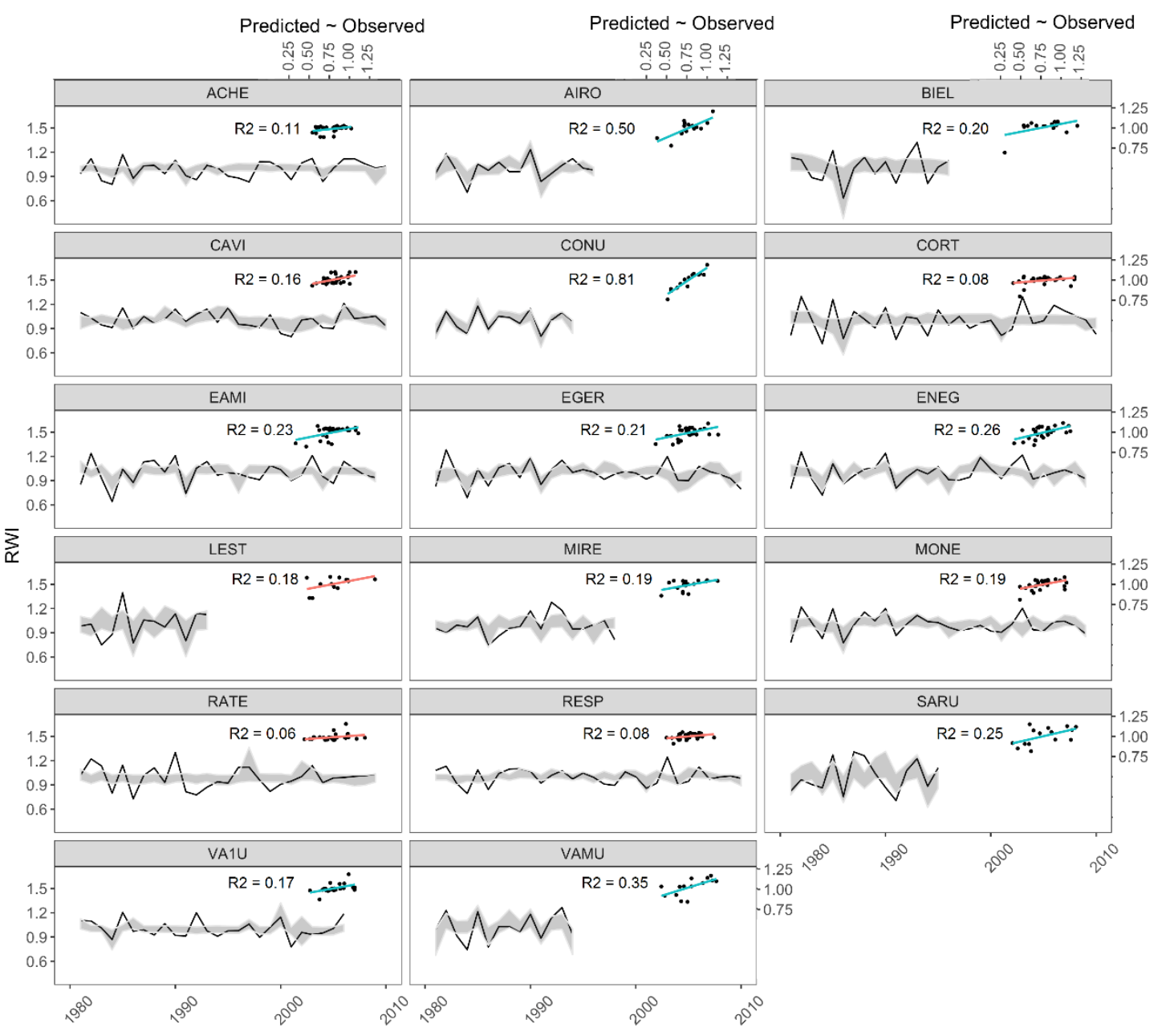


Figure 3. Tree-ring width indices (RWI, lines) and confidence intervals (shaded areas) stepwise linear models for selected sites. Scatter plots show correlatios between observed and RWI values (right y-axes) predicted by the model (adjusted $\mathrm{R}^{2}$ ), and its statistical significance (red: not significant; blue: significant, $p<0.05$ ).

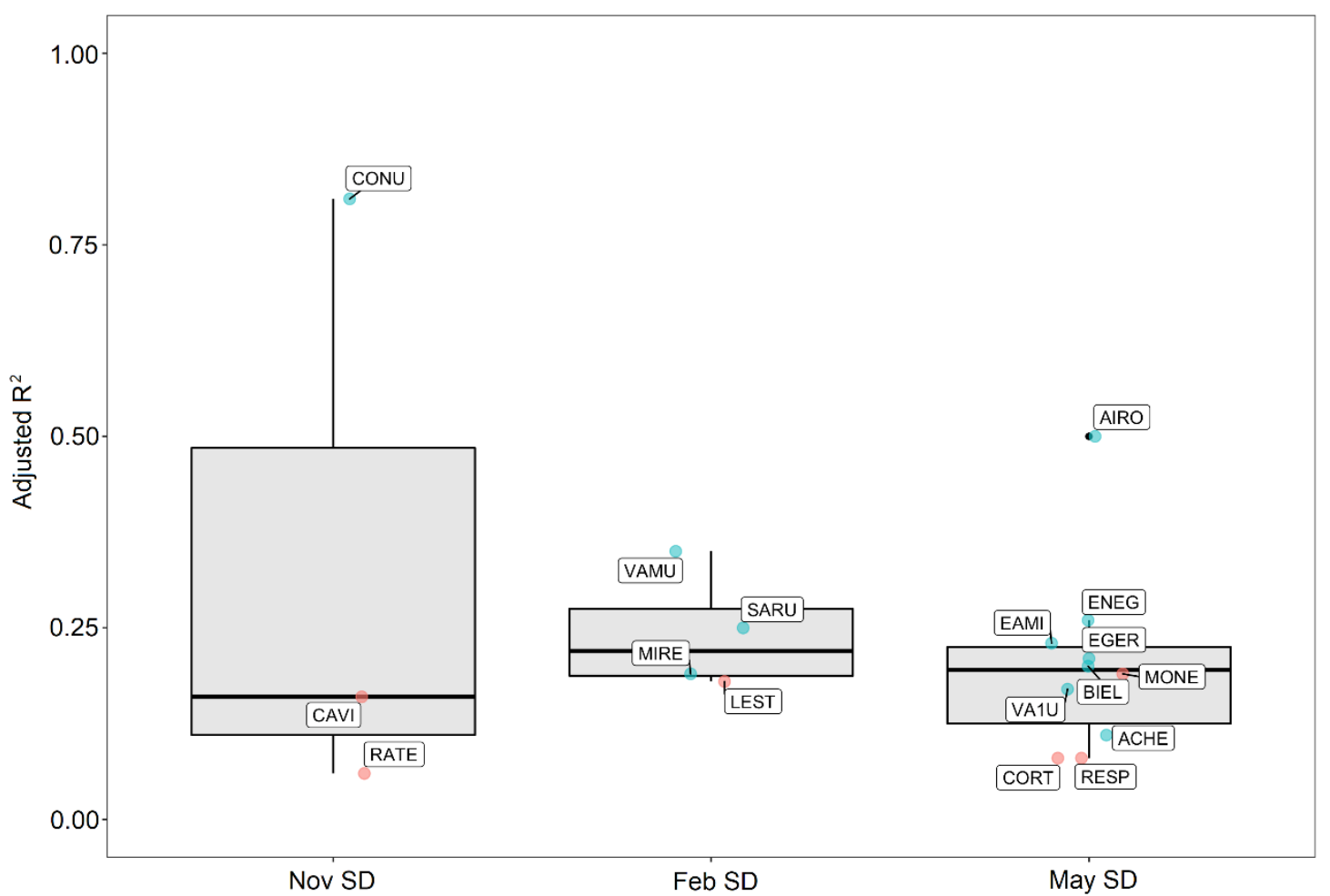

Figure 4. Tree-growth variance (adjusted $\mathrm{R}^{2}$ ) explained by stepwise linear models for selected sites. Values are displayed aggregated by best model predictor (snow indices only). Sites related to each model are labelled. Statistical significance of models is represented in red $(p>0.05)$ and blue $(p<0.05)$ colors. See sites codes in Table S1 and Figure 2.

\subsection{Influence of biogeographical patterns and tree characteristics on growth responses} to snow depth.

Tree characteristics determined the response of growth to snow (Fig 5a). The presence of small trees strengthen the linkage between snow and growth in sites where a snow index was the main driver of RWI $\left(r_{s}=-0.61, p=0.03\right)$ (Figure $\left.5 \mathrm{~b}\right)$. It was observed that sites where a snow index was the statistically significant main driver of $P$. uncinata radial growth were mostly located in the Pyrenees (at western and central area of this mountain range), with the exception of one forest stand located in the southern Iberian System 
(VA1U) (Fig S2). May SD was the main RWI predictor across the Pyrenees and also in the southern Iberian System site.

Additional biogeographical analyses based on growth-snow partial correlations showed that greater and statistically significant negative snow influence on tree growth was found in high-elevation sites (Nov SD index) and sites with bigger tree dbh (Feb SD index) (Figure S3).
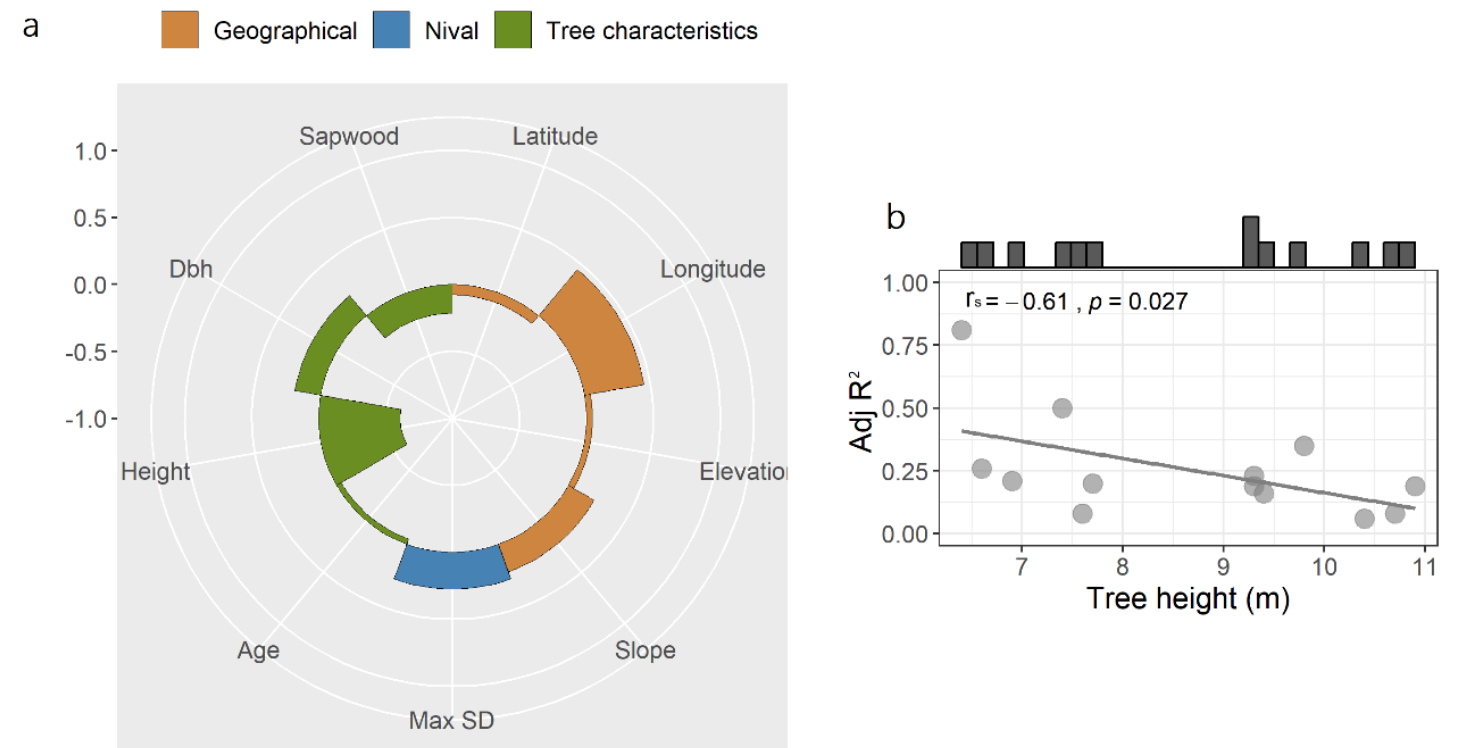

Figure 5. (a) Effects of geographical, nival gradients and tree influences on growth-snow variance (adjusted $\mathrm{R}^{2}$ ) established by Spearman correlations $\left(r_{s}\right)$. The southern Iberian System sites were omitted in latitude analyses. (b) Scatterplot of single obtained statistically significant correlation between growth-snow variance and biogeographical gradients (tree height) $(p<0.05)$. Histograms show sites frequency of distribution along this gradient.

\subsection{Tree radial growth and snow indices trend analysis}

Five of thirteen forests presented statistically significant RWL trends, only one of them showed a positive slope for RWL trend while all the others showed a negative slope (Figure 6b; Figure S4). There were found statistically significant trends for May SD and Feb SD variables, in $35 \%$ and $12 \%$ of sites where snow index was the main driver of $P$. 
uncinata radial growth respectively, but nor for Nov SD. All these statistically significant snow trends show negative slopes.

A statistically significant correlation was found between growth trends (RWL) and snow (Feb SD) trends $\left(r_{s}=-0.68 ; p=0.01\right)$ (Figure 6a). From the regional perspective, only in the Pyrenees there were found statistically significant trends in snow variables (all of them with negative coefficients as mentioned above).

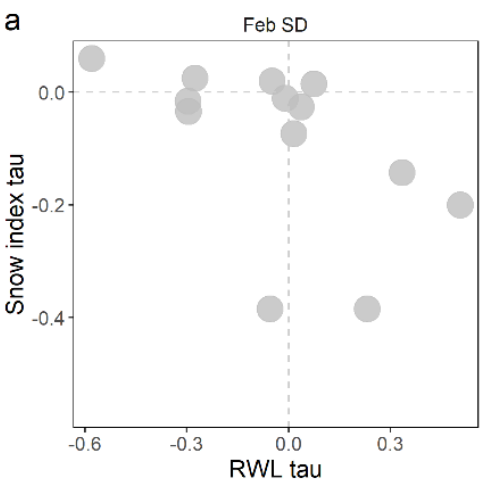

b
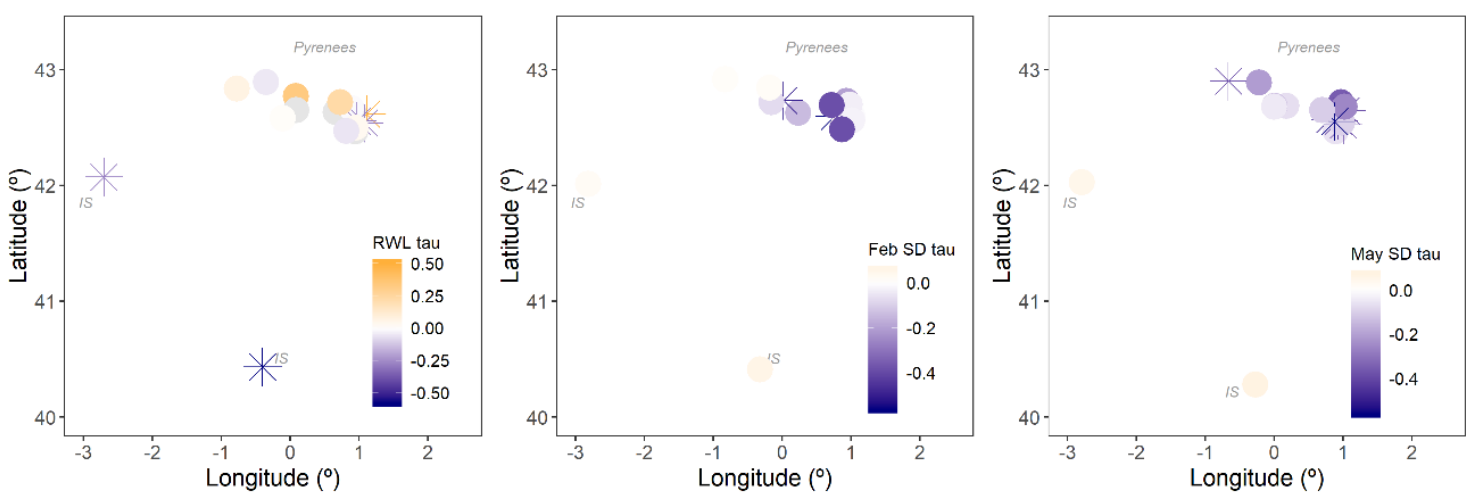

Figure 6. (a) Mann-Kendall linear trends (tau) for tree-ring width (RWL) and Feb SD snow index of selected sites from 1981 to last year with data (see series' lengths in Table S1) and (b) geographical representation of trend analyses results. Pyrenees and Iberian System (IS) locations are indicated.

\section{Discussion}

There is evidence that previous snow cover conditions influence $P$. uncinata tree-ring formation, in addition to the widely reported growing season air temperature effects, as hypothesized. The used methodology allowed us to infer the pure effect of snow on treering growth by controlling the temperature influence on snowpack evolution. First, the most correlated monthly temperature aggregations to snow indices were detected (Table 
S2), including other key temperature indices (May T) for $P$. uncinata growth; second, both temperature and snow indices were taken into account as predictors in radial growth stepwise linear models and by using partial correlations as complementary analyses. Similar procedures were used in Carlson et al. (2017) and Helama et al. (2013). Results provide additional information about the effects of climate on high-elevation $P$. uncinata radial growth. Previous studies showed that radial growth of $P$. uncinata was mainly limited by growing-season air temperature (Rolland and Schueller, 1994; Camarero et al., 1998; Tardif et al., 2003; Andreu et al., 2007; Galván et al., 2014) and, only in certain drought-prone sites, by low early summer precipitation (Andreu et al., 2007; Galván et al., 2014).

The influence of snow cover on radial growth had not been researched for $P$. uncinata, but it has been researched for other species of Pinaceae (Walsh et al., 1994; Kirdyanov et al., 2003; Helama et al., 2013; Watson and Luckman, 2016; Carlson et al., 2017; Franke et al., 2017; Appleton and St. George, 2018; Fkiri et al., 2018; LegendreFixx et al., 2018; Truettner et al., 2018). In this study, almost half the sampled forests in the main mountain ranges of the NE Iberian Peninsula showed certain snow-growth interaction (most of them were statistically significant).

The date of cambial initiation is a key factor for climate-growth associations. This date is related to the date when snowmelt occurs (Kirdyanov et al., 2003) and, consequently, with snow accumulation throughout the winter. The presence of abundant snowpack in late spring may induce a late melt-out and, as a result, a delay in the onset of the $P$. uncinata growing season because the persistent snow cover may cool the soil (Kirdyanov et al., 2003; Helama et al., 2013). This would explain the dominant negative spring snow (May SD index) influence on P. uncinata annual growth found in this study (Table 1, Figure 4). In this regard, Franke et al. (2017) reported that the average monthly 
snow cover during the current year's May correlated negatively with $P$. sylvestris chronologies. Likewise, northern conifers showed delayed cambial activity when snow melt was delayed in the beginning of the growing season (Vaganov et al., 1999; Kirdyanov et al., 2003). Previous studies of $P$. uncinata have demonstrated that this pine species is negatively affected by the preceding growing-season low air temperatures because the onset of cambial activity is triggered by a typical rise in temperature during spring (Tardif et al., 2003; Galvan et al., 2014). Since no positive relation was found between May SD snow index and RWI series in the performed models, we cannot report that moisture from spring snowmelt promotes annual growth of $P$. uncinata in sampled forests. The positive influence of snow on tree growth, explained by a moisturelimitation, widely reported in more arid places as well as in large snow accumulation areas (St. George, 2014; Watson and Luckman, 2016; Carlson et al., 2017), was not detected in the few possible drought-prone sites (Pre-Pyrenees and southern Iberian System) sampled in this study. Winter precipitation is less likely to contribute to the soil moisture reservoir used by trees during the following growing season if spring precipitation is abundant and shows low year-to-year variability as is the case. Spring rainfalls would introduce an extra source of water that would sum up to the water from snowmelt, and thus, the positive influence of snow on tree growth based on moisturelimitation was not detected.

As discussed above, large winter snow accumulation likely produces larger snow presence in spring and this, in turn, causes a delayed melt-out. It is not easy to isolate the impact of winter snow on radial growth, compared to that of late spring snow, because they both are related; however, we did observe that May SD was selected $60 \%$ more than Feb SD as best predictor of RWI in the performed models (Table 1). In this regard, Watson and Luckman (2016) evidenced a relation between larger snow accumulation and 
delays in P. ponderosa and Pseudotsuga menziesii growing seasons in some regions of Canada. Fkiri et al. (2018) also reported that winter snow is a major factor limiting growth of $P$. nigra in NW Tunisia. Other studies, however, pointed to a positive influence of winter snowfall on tree-ring growth due to snowmelt waters may constitute much of the available resource to trees during the beginning of the following growing season (e.g. St. George, 2014).

A possible explanation for the scarce influence of preceding November snow conditions on growth observed in our study is that occasional early-season snowfalls before November did not contribute to overall autumn snow accumulation, thus it was relegated to accumulation occurred in the season last month. As a consequence, small snowpacks were found in November. Furthermore, this late autumn snow depth accumulation has a minor influence on the presence of late spring snow (Nov SD and May SD indices were not correlated, $r_{s}=0.33$ ), which was pointed out in this study as the most important seasonal snow component influencing $P$. uncinata growth. Contrary to our results, Carlson et al. (2017) in P. albicaulis forests and Helama et al. (2013) in $P$. sylvestris forests detected significant negative effects of autumn snowfall and autumn snow depth on radial growth, respectively. The early snowfall in autumn and soil cooling can be related to the cessation and shortening of the growing season (Carlson et al., 2017). In this instance, other physiological tree processes are affected: among others, (1) the reduction of photosynthate storage for the following year growth resumption (Fritts, 1976), (2) the reduction of mycorrhizal activity (Peterson and Peterson, 1994), and (3) the inhibition of carbon transfer into radial growth and later carbon storage for the following year (Hoch and Körner, 2003). Moreover, previous studies have demonstrated that $P$. uncinata is sensitive to previous November low temperatures, when synthesis and 
storage of carbohydrates can affect later radial growth (Tardif et al., 2003; Galván et al., 2014).

Evidence of tree characteristics' influence on the snow-radial growth relationship was found. Smaller trees showed to be more sensitive to snow effects (Figure 5b), which could be due to a more efficient hydraulic functioning (Galván et al. 2012) or to a lower influence of snowpack on microclimate and phenology in the case of tall trees. Zhu et al. (2015) reported that large trees have higher recovery rates from snow damage than smaller trees. With regard to geographical distribution of snow-growth interactions, in the Pyrenean sites (central and western areas) occurred almost all of the significant snowgrowth correlations, but also the negative snow-growth influence was detected in the drier Iberian System site. Any snow influence on P. uncinata growth was found in the PrePyrenees or eastern Pyrenees sampled sites. Previous studies (Tardif et al., 2003; Galván et al., 2014) have demonstrated that elevation plays a major role in P. uncinata radial growth-index responses to climate. Galván et al. (2014) observed an elevation pattern regarding temperature: November temperature conditions during the year prior to treering formation influence $P$. uncinata growth mainly in mid-elevation sites, whereas at higher elevations, growth was more dependent on May temperature conditions during the year of tree-ring formation. However, no statistical significant relation was found regarding the elevation gradient determine whether $P$. uncinata radial growth is influenced by a specific snow index. Thought results from partial correlation analyses indicate that the main negative snow influences on tree growth were found at higher elevations (Figure S3), this study did not produce sufficient evidence to confirm our initial hypothesis. We expected that upper and therefore colder forest sites could be the most sensitive to snow-growth influences. The decrease in near-surface air temperature produced by an increase in elevation (Navarro-Serrano et al., 2018) was suggested to limit 
the maximum elevation of tree growth due to a short growing season (Körner, 2012). Consequently, snow conditions could be expected to be the most limiting factor for radial growth at high elevations which further reduces $P$. uncinata growth period, especially linked to late spring snow cover. But more detailed information on elevational gradients of snow features are needed to test it.

Significant and decreasing trends were detected in winter and spring snow depths along the Pyrenees (although trend coefficients are very dependent on the selected study period), similar to other main mid-latitude mountain ranges (López-Moreno, 2005; Marty, 2008; McCabe and Wolock, 2009; Beniston, 2012; Morán-Tejeda et al., 2013a; Buisan et al., 2015) (Figure 6b). A significant and negative response of $P$. uncinata growth to the negative trends in winter snow was found (Figure 6a), but it was not ubiquitous. Thus, trends of $P$. uncinata growth were not consistent through all forests, thought almost all the statistically significant coefficients found were negative (only there was one increasing growth trend). This may be related, however, to the length of the radial growth data series. Overall results suggest that $P$. uncinata radial growth could benefit from the predicted shallower snowpack in these mountain ranges (López-Moreno, 2005; Morán-Tejeda et al., 2013a) over the next decades by a prolongation of the growing season, especially in high elevation forests. Likewise, climatic warming is expected to promote forest growth in the Pyrenees in a similar way (Tardif et al., 2003). However, growth could be declined in some dry sites where the amount of soil water available to trees in the growing season relates to the previous months' snowpack (Pederson et al., 2011). Therefore, in xeric sites, a shallower snowpack due to warmer temperatures could lead to limited soil water content in spring and reduce growth (Walsh et al., 1994; Truettner et al., 2018). It has been reported that these thermal stress sites are dependent on early summer precipitation (Richter et al., 1991; Andreu et al., 2007; Galván et al., 
517 2014), but this has not been observed so far in our studied sites. This may be related to

518 limitation in the data used in this study. The length of the radial growth data series was 519 not consistent throughout the sampled sites, ranging from 30 to 13 years of available data

520 per sampled forest. The temperature and snow depth data were a product of a climate 521 simulation with the WRF model, with a spatial resolution $(10 \times 10 \mathrm{~km})$ that could be too 522 coarse to represent their real spatial variability on the complex terrains of the forests. The observations. induced drought stress. 
540 This study was funded by the Spanish Ministry of Economy and Competitiveness [grant 541 numbers CGL2014-52599-P, CGL2017-82216-R]. A. Sanmiguel-Vallelado is supported 542 by a University Professor Training grant [grant number FPU16/00902] funded by the 543 Spanish Ministry of Education, Culture and Sport.

544

545

546

547

548

549

\section{Acknowledgements}

We thank all management personnel and forest guards connected to the National Parks or protected areas sampled in this study for their support. We also thank AEMET and CHE for providing climate data. 


\section{References}

Alonso-González, E., López-Moreno, J.I., Gascoin, S., García-Valdecasas Ojeda, M., Sanmiguel-Vallelado, A., Navarro-Serrano, F., Revuelto, J., Ceballos, A., Esteban-Parra, M.J., Essery, R., 2018. Daily gridded datasets of snow depth and snow water equivalent for the Iberian Peninsula from 1980 to 2014. Earth Syst. Sci. Data 10, 303-315. https://doi.org/10.5194/essd-10-303-2018

Andreu, L., Gutiérrez, E., Macias, M., Ribas, M., Bosch, O., Camarero, J.J., 2007. Climate increases regional tree-growth variability in Iberian pine forests. Glob. Change Biol. 13, 804-815. https://doi.org/10.1111/j.1365-2486.2007.01322.x

Appleton, S.N., St. George, S., 2018. High-elevation mountain hemlock growth as a surrogate for cool-season precipitation in Crater Lake National Park, USA. Dendrochronologia 52, 20-28. https://doi.org/10.1016/j.dendro.2018.09.003

Barton, K., Barton, M.K., 2018. Package 'MuMIn.’ Model selection and model averaging based on information criteria. $\mathrm{R}$ package version 3.5.1. R Foundation for Statistical Computing, Vienna, Austria.

Beniston, M., 2003. Climatic change in mountain regions: a review of possible impacts, in: Climate Variability and Change in High Elevation Regions: Past, Present \& Future. Springer, 5-31.

Beniston, M., 2012. Is snow in the Alps receding or disappearing? Wiley Interdiscip. Rev. Clim. Change 3, 349-358. https://doi.org/10.1002/wcc.179

Beniston, M., Uhlmann, B., Goyette, S., Lopez-Moreno, J.I., 2011. Will snow-abundant winters still exist in the Swiss Alps in an enhanced greenhouse climate? Int. J. Climatol. 31, 1257-1263. https://doi.org/10.1002/joc.2151

Berrisford, P., D. Dee, P. Poli, R. Brugge, K. Fielding, M. Fuentes, P. Kallberg, S. Kobayashi, S. Uppala, Simmons, A., 2011. The ERA-Interim archive version 
Bronaugh, D., Werner, A., Bronaugh, M.D., 2009. Package 'zyp.' CRAN Repos.

Buisán, S. T., Saz Sánchez M.A., López-Moreno, J.I, 2015. Spatial and temporal variability of winter snow and precipitation days in the western and central Spanish Pyrenees. Int. J. Climatol. 35, 259-274. https://doi.org/10.1002/joc.3978.

Burnham, K.P., Anderson, D.R., 2003. Model selection and multimodel inference: a practical information-theoretic approach. Springer Science \& Business Media.

Camarero, J. J., Gazol, A., Galván, J.D., Sanguesa-Barreda, G., Gutiérrez., E., 2015a. Disparate effects of global-change drivers on mountain conifer forests: warming-induced growth enhancement in young trees vs. $\mathrm{CO}_{2}$ fertilization in old trees from wet sites. Glob. Change Biol. 21: 738-749. https://doi.org/10.1111/gcb.12787.

Camarero, J.J., Gazol, A., Sancho-Benages, S. and Sanguesa-Barreda, G., 2015b. Know your limits? Climate extremes impact the range of Scots pine in unexpected places. Ann. Bot. 116: 917-927. https://doi.org/10.1093/aob/mcv124

Camarero, J.J., Gazol, A., Tardif, J.C. and Conciatori, F. 2015c. Attributing forest responses to global-change drivers: limited evidence of a $\mathrm{CO} 2$-fertilization effect in Iberian pine growth. J. Biogeogr.y 42: 2220-2233.

Camarero, J.J., Guerrero-Campo, J., Gutiérrez, E., 1998. Tree-ring growth and structure of Pinus uncinata and Pinus sylvestris in the Central Spanish Pyrenees. Arct. Alp. Res. 30, 1-10.

Camarero, J.J., Linares, J.C., García-Cervigón, A.I., Batllori, E., Martínez, I., Gutiérrez, E., 2017. Back to the future: the responses of alpine treelines to climate warming are constrained by the current ecotone structure. Ecosystems 20, 683-700. 
https://doi.org/10.1007/s10021-016-0046-3

Cantegrel, R., 1983. Le Pin à crochets pyrénéen: biologie, biochimie, sylviculture. Acta Biol. Mont. 2, 87-330.

Carlson, K.M., Coulthard, B., Starzomski, B.M., 2017. Autumn snowfall controls the annual radial growth of centenarian whitebark pine (Pinus albicaulis) in the southern Coast Mountains, British Columbia, Canada. Arct. Antarct. AlP. Res. 49, 101-113. https://doi.org/10.1657/AAAR0016-033

Cook, E.R., 1985. A time series analysis approach to tree ring standardization (dendrochronology, forestry, dendroclimatology, autoregressive process). Dissertation, The University of Arizona.

D’Orangeville, L., Houle, D., Duchesne, L., Phillips, R. P., Bergeron, Y., Kneeshaw, D., 2018. Beneficial effects of climate warming on boreal tree growth may be transitory. Nat. Commun., 9(1), 3213. DOI: 10.1038/s41467-018-05705-4

Del Barrio, G., Creus, J., Puigdefábregas, J., 1990. Thermal seasonality of the high mountain belts of the Pyrenees. Mt. Res. Dev. 227-233.

El Kenawy, A., López-Moreno, J.I., Vicente-Serrano, S.M., 2011. Recent trends in daily temperature extremes over northeastern Spain (1960-2006). Nat. Hazards Earth Syst. Sci. 11, 2583-2603. https://doi.org/10.5194/nhess-11-2583-2011

Essery, R., 2015. A factorial snowpack model (FSM 1.0). Geosci. Model Dev. 8(12), 3867-3876. doi:10.5194/gmd-8-3867-2015

Fkiri, S., Guibal, F., Fady, B., Khorchani, A.E., Khaldi, A., Khouja, M.L., Nasr, Z., 2018. Tree-rings to climate relationships in nineteen provenances of four black pines sub-species (Pinus nigra Arn.) growing in a common garden from Northwest Tunisia. Dendrochronologia 50, 44-51. https://doi.org/10.1016/j.dendro.2018.05.001 
Franke, A.K., Bräuning, A., Timonen, M., Rautio, P., 2017. Growth response of Scots pines in polar-alpine tree-line to a warming climate. For. Ecol. Manag. 399, 94107. https://doi.org/10.1016/j.foreco.2017.05.027

Fritts, H.C., 1976. Tree rings and Climate. Acad. San Diego Calif., 567 pp.

Galván, D.J., Büntgen, U., Ginzler, C., Grudd, H., Gutiérrez, E., Labuhn, I. and Camarero, J.J. 2015. Drought-induced weakening of growth-temperature associations in high-elevation Iberian pines. Glob. Planet. Ch. 124, 95-106.

Galván, J.D., Camarero, J.J., Gutiérrez, E., 2014. Seeing the trees for the forest: drivers of individual growth responses to climate in Pinus uncinata mountain forests. J. Ecol. 102, 1244-1257. https://doi.org/10.1111/1365-2745.12268

Galván, J.D., Camarero, J.J., Sangüesa-Barreda, G., Alla, A.Q., Gutiérrez, E., 2012. Sapwood area drives growth in mountain conifer forests. J. Ecol. 100, 12331244. https://doi.org/10.1111/j.1365-2745.2012.01983.x

García-Ruiz, J.M., Puigdefábregas, T.J., Creus-Novau, J., 1985. Los recursos hídricos superficiales del Alto Aragón. Instituto de Estudios Altoaragoneses, 224 pp.

Gutiérrez, E., 1991. Climate-tree-growth relationships for Pinus uncinata Ram. in the Spanish pre-Pyrenees. Acta Oecol. 12, 213-225.

Helama, S., Mielikainen, K., Timonen, M., Herva, H., Tuomenvirta, H., Venalainen, A., 2013. Regional climatic signals in Scots pine growth with insights into snow and soil associations. Dendrobiology 70: 27-34. http://dx.doi.org/10.12657/denbio.070.003

Hoch, G., Körner, C., 2003. The carbon charging of pines at the climatic treeline: a global comparison. Oecologia 135, 10-21. https://doi.org/10.1007/s00442-0021154-7

Holmes, R.L., 1983. Computer-assisted quality control in tree-ring dating and 

measurement. Tree-Ring Bull.

Innes, J.L., 1991. High-altitude and high-latitude tree growth in relation to past, present and future global climate change. The Holocene 1: 168-173. https://doi.org/10.1177/095968369100100210.

Kirdyanov, A., Hughes, M., Vaganov, E., Schweingruber, F., Silkin, P., 2003. The importance of early summer temperature and date of snow melt for tree growth in the Siberian Subarctic. Trees 17, 61-69. https://doi.org/10.1007/s00468-0020209-Z

Körner, C., 2012. Alpine Treelines: Functional Ecology of the Global High Elevation Tree Limits. Springer.

Legendre-Fixx, M., Anderegg, L.D.L., Ettinger, A.K., HilleRisLambers, J., 2018. Siteand species-specific influences on sub-alpine conifer growth in Mt. Rainier National Park, USA. Forests 9, 1. https://doi.org/10.3390/f9010001

López-Moreno, J.I., 2005. Recent variations of snowpack depth in the Central Spanish Pyrenees. Arct. Antarct. Alp. Res. 37, 253-260. https://doi.org/10.1657/15230430(2005)037[0253:RVOSDI]2.0.CO;2

López-Moreno, J.I., Morán-Tejeda, E., Vicente Serrano, S.M., Lorenzo-Lacruz, J., García-Ruiz, J.M., 2011. Impact of climate evolution and land use changes on water yield in the Ebro basin. Hydrol. Earth. Syst. Sci. 15, 311-322. http://dx.doi.org/10.5194/hess-15-311-2011

López-Moreno, J.I., Vicente-Serrano, S.M., Angulo-Martínez, M., Beguería, S., Kenawy, A., 2010. Trends in daily precipitation on the northeastern Iberian Peninsula, 1955-2006. Int. J. Climatol. 30, 1026-1041. https://doi.org/10.1002/joc.1945

Marty, C., 2008. Regime shift of snow days in Switzerland. Geophys. Res. Lett. 35, 
McCabe, G.J., Wolock, D.M., 2009. Recent declines in western US snowpack in the context of twentieth-century climate variability. Earth Interact. 13, 1-15. https://doi.org/10.1175/2009EI283.1

Morán-Tejeda, E., Herrera, S., López-Moreno, J.I., Revuelto, J., Lehmann, A., Beniston, M., 2013a. Evolution and frequency (1970-2007) of combined temperature-precipitation modes in the Spanish mountains and sensitivity of snow cover. Reg. Environ. Change 13, 873-885. https://doi.org/10.1007/s10113012-0380-8

Morán-Tejeda, E., López-Moreno, J. I., Stoffel, M., Beniston, M., 2016. Rain-on-snow events in Switzerland: recent observations and projections for the 21st century. Clim. Res. 71, 111-125. https://doi.org/10.3354/cr01435

Morán-Tejeda, E., López-Moreno, J.I., Beniston, M., 2013b. The changing roles of temperature and precipitation on snowpack variability in Switzerland as a function of altitude. Geophys. Res. Lett. 40, 2131-2136. https://doi.org/10.1002/grl.50463

Morán-Tejeda, E., López-Moreno, J.I., Sanmiguel-Vallelado, A., 2017. Changes in climate, snow and water resources in the Spanish Pyrenees: observations and projections in a warming climate, in: Catalan, J., Ninot, J. M., Aniz, M. M. (Eds.), High Mountain Conservation in a Changing World. Springer, pp. 305323.

Morán-Tejeda, E., Lorenzo-Lacruz, J., López-Moreno, J.I., Rahman, K., Beniston, M., 2014. Streamflow timing of mountain rivers in Spain: recent changes and future projections. J. Hydrol. 517, 1114-1127. https://doi.org/10.1016/j.jhydrol.2014.06.053 
Navarro-Serrano, F., I. López-Moreno, J., Azorin-Molina, C., Alonso-González, E., Tomás-Burguera, M., Sanmiguel-Vallelado, A., Revuelto, J., Beguería, S., 2018. Estimation of near-surface air temperature lapse rates over continental Spain and its mountain areas. Int. J. Climatol. 38, 3233-3249. https://doi.org/10.1002/joc.5497

Pederson, G.T., Gray, S.T., Woodhouse, C.A., Betancourt, J.L., Fagre, D.B., Littell, J.S., Watson, E., Luckman, B.H., Graumlich, L.J., 2011. The Unusual Nature of Recent Snowpack Declines in the North American Cordillera. Science 333, 332335. https://doi.org/10.1126/science. 1201570

Peterson, D.W., Peterson, D.L., 1994. Effects of climate on radial growth of subalpine conifers in the North Cascade Mountains. Can. J. For. Res. 24, 1921-1932. https://doi.org/10.1139/x94-247

R Core Team, 2014. R: A language and environment for statistical computing. R Foundation for Statistical Computing, Vienna, Austria.

Revuelto, J., López-Moreno, J.I., Morán Tejeda, E., Fassnacht, S., Serrano, V., Martín, S., 2012. Variabilidad interanual del manto de nieve en el Pirineo: tendencias observadas y su relación con índices de teleconexión durante el periodo 1985 2011, in: Rodríguez, C., Ceballos, A., González, N., Morán-Tejeda, E., Pacheco S., Hernández, A. (Eds.), Cambio climático. Extremos e impactos. Asociación Española de Climatología, Salamanca, pp. 613-621.

Rolland, C., Schueller, J.F., 1994. Relationships between mountain pine and climate in the French Pyrenees (Font-Romeu) studied using the radiodensitometrical method. Pirineos 143, 55-70. https://doi.org/10.3989/pirineos.1994.v143144.156

Sanchez-Salguero, R., Camarero, J., Gutiérrez, E., Gazol, A., Sangüesa-Barreda, G., 
Moiseev, P., Linares, J., 2018. Climate Warming Alters Age-Dependent Growth Sensitivity to Temperature in Eurasian Alpine Treelines. Forests 9, 688. DOI: $10.3390 /$ f9110688

Sánchez-Salguero, R., Navarro-Cerrillo, R.M., Swetnam, T.W., Zavala, M.A., 2012. Is drought the main decline factor at the rear edge of Europe? The case of southern Iberian pine plantations. For. Ecol. Manage. 271, 158-169. https://doi.org/10.1016/j.foreco.2012.01.040

Sangüesa-Barreda, G., Camarero, J.J., Esper, J., Galván, J.D., Büntgen, U., 2018. A millennium-long perspective on high-elevation pine recruitment in the Spanish central Pyrenees. Can. J. For. Res. 1113, 1108-1113.

Skamarock, W. C., Klemp, J. B., Dudhia, J., Gill, D. O., Barker, D. M., Dudha, M. G., Huang, X., Wang, W., Powers, Y., 2008. A Description of the Advanced Research WRF Version 3. NCAR Tech. Note NCAR/TN-475+STR. https://doi.org/10.5065/D68S4MVH

Smithers, B.V., North, M.P., Millar, C.I., Latimer, A.M., 2018. Leap frog in slow motion: Divergent responses of tree species and life stages to climatic warming in Great Basin subalpine forests. Glob. Change Biol. 24, 442-457. https://doi.org/10.1111/gcb.13881

St. George, S., 2014. An Overview of Tree-Ring Width Records across the Northern Hemisphere. Quat. Sci. Rev. 95, 132-150. https://doi.org/10.1016/j.quascirev.2014.04.029.

Tardif, J., Camarero, J.J., Ribas, M., Gutiérrez, E., 2003. Spatiotemporal variability in tree growth in the Central Pyrenees: climatic and site influences. Ecol. Monogr. 73, 241-257. https://doi.org/10.1890/00129615(2003)073[0241:SVITGI]2.0.CO;2 
Truettner, C., Anderegg, W.R.L., Biondi, F., Koch, G.W., Ogle, K., Schwalm, C., Litvak, M.E., Shaw, J.D., Ziaco, E., 2018. Conifer radial growth response to recent seasonal warming and drought from the southwestern USA. For. Ecol. Manage. 418, 55-62. https://doi.org/10.1016/j.foreco.2018.01.044

Vaganov EA, Hughes MK, Kirdyanov AV, Schweingruber FH, Silkin PP. 1999. Influence of snowfall and melt timing on tree growth in subarctic Eurasia. Nature 400: 149-151. https://doi.org/10.1038/22087

Walsh, S.J., Butler, D.R., Allen, T.R., Malanson, G.P., 1994. Influence of snow patterns and snow avalanches on the alpine treeline ecotone. J. Veg. Sci. 5, 657-672. https://doi.org/10.2307/3235881

Wang, X., Pederson, N., Chen, Z., Lawton, K., Zhu, C., Han, S., 2019. Recent rising temperatures drive younger and southern Korean pine growth decline. Sci. Total Environ. 649, 1105-1116. DOI: 10.1016/j.scitotenv.2018.08.393

Watson, E., Luckman, B.H., 2016. An investigation of the snowpack signal in moisturesensitive trees from the Southern Canadian Cordillera. Dendrochronologia 38, 118-130. https://doi.org/10.1016/j.dendro.2016.03.008

Zhu, L., Zhou, T., Chen, B., Peng, S., 2015. How does tree age influence damage and recovery in forests impacted by freezing rain and snow? Sci. China Life Sci. 58, 472-479. https://doi.org/10.1007/s11427-014-4722-2

Zhuang, L., Axmacher, J.C., Sang, W., 2017. Different radial growth responses to climate warming by two dominant tree species at their upper altitudinal limit on Changbai Mountain. J. For. Res. 28, 795-804. https://doi.org/10.1007/s11676016-0364-5 


\section{Supplementary Material}

775 Table S1. Pinus uncinata sampled sites and their geographical, topographical, ecological 776 and nival characteristics. Values are means \pm standard deviation.

\begin{tabular}{|c|c|c|c|c|c|c|c|c|c|}
\hline $\begin{array}{c}\text { Mountain } \\
\text { range }\end{array}$ & Site (code) & $\begin{array}{c}\text { Analysed } \\
\text { years }\end{array}$ & $\begin{array}{l}\text { Latitude } \\
\mathrm{N}\left({ }^{\circ}\right)\end{array}$ & $\begin{array}{l}\text { Longitude } \\
-\mathrm{W},+\mathrm{E}\left({ }^{\circ}\right)\end{array}$ & $\begin{array}{c}\text { Elevation } \\
\text { (m a.s.1.) }\end{array}$ & Slope $\left({ }^{\circ}\right)$ & $\mathrm{dbh}(\mathrm{cm})$ & Age (years) & $\operatorname{Max} \operatorname{SD}(\mathrm{m})$ \\
\hline \multirow{30}{*}{ Pyrenees } & Acherito (ACHE) & 30 & 42.89 & -0.75 & 1850 & - & - & - & $2.31 \pm 0.61$ \\
\hline & Airoto (AIRO) & 16 & 42.70 & 1.03 & 2300 & $47 \pm 29$ & $58.5 \pm 13.5$ & $288 \pm 100$ & $2.54 \pm 0.70$ \\
\hline & Bielsa (BIEL) & 16 & 42.70 & 0.18 & 2000 & $88 \pm 4$ & $45.1 \pm 9.4$ & $270 \pm 67$ & $1.14 \pm 0.36$ \\
\hline & Barranc de Llacs (BLLA) & 30 & 42.53 & 0.92 & 2250 & $44 \pm 38$ & $71.7 \pm 20.0$ & $616 \pm 175$ & $2.65 \pm 0.86$ \\
\hline & Conangles (CONU) & 14 & 42.62 & 0.73 & 2106 & $43 \pm 15$ & $56 \pm 14.5$ & $318 \pm 117$ & $1.94 \pm 0.61$ \\
\hline & Corticelles-Delluí (CORT) & 30 & 42.56 & 0.93 & 2269 & $24 \pm 17$ & $83.1 \pm 28.8$ & $509 \pm 177$ & $1.26 \pm 0.47$ \\
\hline & Las Cutas (CUTA) & 17 & 42.62 & -0.08 & 2150 & $20 \pm 5$ & $33.3 \pm 8.3$ & $129 \pm 16$ & $1.31 \pm 0.49$ \\
\hline & Estany d'Amitges (EAMI) & 29 & 42.58 & 0.98 & 2390 & $40 \pm 21$ & $69 \pm 26.0$ & $355 \pm 106$ & $1.51 \pm 0.59$ \\
\hline & Estany Gerber (EGER) & 30 & 42.62 & 0.98 & 2268 & $15 \pm 15$ & $53.5 \pm 14.6$ & $426 \pm 147$ & $2.24 \pm 0.64$ \\
\hline & Estany de Lladres (ELLA) & 29 & 42.55 & 1.05 & 2120 & $35 \pm 12$ & $52.1 \pm 9.8$ & $313 \pm 123$ & $1.03 \pm 0.54$ \\
\hline & Estany Negre (ENEG) & 29 & 42.55 & 1.03 & 2451 & $35 \pm 18$ & $71 \pm 26.0$ & $411 \pm 182$ & $1.68 \pm 0.66$ \\
\hline & Estanys de la Pera (EPER) & 17 & 42.45 & 1.61 & 2360 & $30 \pm 0$ & $65.2 \pm 11.0$ & $339 \pm 117$ & $0.94 \pm 0.39$ \\
\hline & Foratarruego (FORA) & 29 & 42.62 & 0.10 & 2031 & $37 \pm 11$ & $49.5 \pm 18.3$ & $433 \pm 50$ & $1.83 \pm 0.83$ \\
\hline & Larra (LACO) & 19 & 42.95 & -0.77 & 1750 & $38 \pm 24$ & $46.4 \pm 14.0$ & $350 \pm 108$ & $1.90 \pm 0.53$ \\
\hline & La Estiva (LEST) & 13 & 42.68 & 0.08 & 2000 & - & - & - & $1.10 \pm 0.32$ \\
\hline & Mata de València (MAVA) & 17 & 42.63 & 1.07 & 2019 & $19 \pm 10$ & $43.2 \pm 3.6$ & $237 \pm 72$ & $1.65 \pm 0.58$ \\
\hline & Mirador (MIRA) & 29 & 42.58 & 0.98 & 2180 & $33 \pm 18$ & $55.1 \pm 25.8$ & $401 \pm 132$ & $1.06 \pm 0.41$ \\
\hline & Mirador del Rey (MIRE) & 18 & 42.63 & -0.07 & 1980 & $25 \pm 10$ & $53.3 \pm 15.3$ & $117 \pm 18$ & $0.94 \pm 0.29$ \\
\hline & Monestero (MONE) & 29 & 42.56 & 0.98 & 2280 & $28 \pm 13$ & $64.4 \pm 16.1$ & $346 \pm 110$ & $1.28 \pm 0.49$ \\
\hline & Vall de Núria (NURI) & 21 & 42.38 & 2.13 & 2075 & - & - & - & $0.49 \pm 0.27$ \\
\hline & Pic d'Arnousse (PIAR) & 14 & 42.80 & -0.52 & 1940 & $32 \pm 4$ & $65.4 \pm 5.1$ & $248 \pm 83$ & $2.80 \pm 0.67$ \\
\hline & Ratera (RATE) & 29 & 42.58 & 0.98 & 2170 & $40 \pm 5$ & $28.3 \pm 8.1$ & $380 \pm 146$ & $1.04 \pm 0.40$ \\
\hline & Respomuso (RESP) & 30 & 42.82 & -0.28 & 2350 & $70 \pm 19$ & $49.5 \pm 15.1$ & $280 \pm 83$ & $4.61 \pm 1.17$ \\
\hline & Sant Maurici (SAMA) & 16 & 42.58 & 0.98 & 1933 & $16 \pm 15$ & $38.2 \pm 5.7$ & $204 \pm 23$ & $0.67 \pm 0.22$ \\
\hline & Sarradé (SARU) & 15 & 42.55 & 0.89 & 1950 & - & - & - & $1.65 \pm 0.51$ \\
\hline & Senda de Cazadores (SECA) & 29 & 42.63 & -0.05 & 2247 & $49 \pm 12$ & $60.9 \pm 16.5$ & $337 \pm 145$ & $1.60 \pm 0.76$ \\
\hline & Setcases (SETU) & 19 & 42.40 & 2.28 & 2080 & - & - & - & $0.68 \pm 0.35$ \\
\hline & Sobrestivo (SOBR) & 29 & 42.67 & 0.10 & 2296 & $38 \pm 2$ & $61.7 \pm 17.5$ & $341 \pm 97$ & $2.06 \pm 0.88$ \\
\hline & Tessó de Son (TESO) & 15 & 42.58 & 1.03 & 2239 & $42 \pm 14$ & $74.5 \pm 18.8$ & $346 \pm 202$ & $1.15 \pm 0.37$ \\
\hline & Vall de Mulleres (VAMU) & 14 & 42.62 & 0.72 & 1800 & $34 \pm 13$ & $69 \pm 26.0$ & $437 \pm 184$ & $1.27 \pm 0.35$ \\
\hline \multirow{3}{*}{$\begin{array}{c}\text { Pre- } \\
\text { Pyrenees }\end{array}$} & Cap de Boumort (COLU) & 30 & 42.23 & 1.12 & 1915 & - & - & - & $0.35 \pm 0.22$ \\
\hline & Guara (GUAU) & 30 & 42.28 & -0.25 & 1790 & - & - & - & $0.62 \pm 0.32$ \\
\hline & Pedraforca (PEDR) & 26 & 42.23 & 1.70 & 2100 & - & - & - & $0.69 \pm 0.37$ \\
\hline \multirow{2}{*}{$\begin{array}{l}\text { Iberian } \\
\text { System }\end{array}$} & Vinuesa (CAVI) & 30 & 42.00 & -2.73 & 2050 & $21 \pm 1$ & $85.6 \pm 23.0$ & $368 \pm 148$ & $1.31 \pm 0.39$ \\
\hline & Valdelinares (VATE-VA1U) & 26 & 40.37 & -0.37 & 1955 & $10 \pm 5$ & $63.8 \pm 12.4$ & $214 \pm 107$ & $0.57 \pm 0.32$ \\
\hline
\end{tabular}


779 Table S2. Coefficients from Spearman correlations $\left(r_{s}\right)$ between snow indices and 780 temperature monthly aggregations. Arrow indicates which monthly aggregation of 781 temperature is best correlated to each snow index and is then used in further analysis.

782

\begin{tabular}{clll}
\hline \multirow{2}{*}{ Temperature indices } & \multicolumn{3}{c}{ Snow indices } \\
\cline { 2 - 4 } & Nov SD & Feb SD & May SD \\
\hline Nov T & $-0.34^{* *} \leftarrow$ & \\
Feb T & & $-0.63^{* *}$ \\
Nov-Feb T & $-0.57^{* *}$ \\
Dec-Feb T & $-0.63^{* *}$ & \\
Jan-Feb T & $-0.64^{* *} \leftarrow$ \\
& & \\
May T & & $-0.55^{* *}$ \\
Mar-May T & & $-0.57^{* *} \leftarrow$ \\
Apr-May T & & $-0.56 * *$ \\
\hline
\end{tabular}

783 Values followed by $* *$ are statistically significant at $p<0.01$. 
Table S3. Correlation coefficients from partial correlations calculated between tree-ring width and snow indices.

\begin{tabular}{|c|c|c|c|c|}
\hline \multirow{2}{*}{ Site } & \multirow{2}{*}{$\begin{array}{c}\mathrm{N}^{\mathbf{o}} \\
\text { analysed } \\
\text { years }\end{array}$} & \multicolumn{3}{|c|}{ Spearman correlations coefficients $\left(r_{s}\right)$} \\
\hline & & Nov SD & Feb SD & May SD \\
\hline ACHE & 30 & -0.09 & -0.27 & -0.22 \\
\hline AIRO & 16 & -0.24 & -0.23 & -0.41 \\
\hline BIEL & 16 & 0.32 & -0.34 & -0.12 \\
\hline BLLA & 30 & 0.09 & -0.09 & -0.13 \\
\hline CAVI & 30 & -0.23 & -0.35 & -0.33 \\
\hline COLU & 30 & 0.01 & 0.14 & 0.03 \\
\hline CONU & 14 & -0.06 & $-0.78 * *$ & -0.51 \\
\hline CORT & 30 & -0.02 & -0.26 & -0.18 \\
\hline CUTA & 17 & -0.30 & 0.01 & 0.07 \\
\hline EAMI & 29 & 0.14 & -0.23 & 0.03 \\
\hline EGER & 30 & 0.05 & -0.29 & $-0.38^{*}$ \\
\hline ELLA & 29 & 0.19 & 0.21 & -0.16 \\
\hline ENEG & 29 & 0.06 & -0.23 & -0.12 \\
\hline EPER & 17 & -0.45 & $-0.56^{*}$ & 0.09 \\
\hline FORA & 29 & 0.15 & 0.06 & 0.20 \\
\hline GUAU & 30 & 0.13 & 0.17 & 0.06 \\
\hline LACO & 19 & 0.22 & -0.25 & -0.31 \\
\hline LEST & 13 & 0.14 & -0.31 & 0.31 \\
\hline MAVA & 17 & 0.17 & 0.08 & 0.15 \\
\hline MIRA & 29 & 0.06 & -0.23 & -0.05 \\
\hline MIRE & 18 & -0.05 & -0.47 & 0.37 \\
\hline MONE & 29 & 0.02 & -0.26 & -0.21 \\
\hline NURI & 21 & 0.11 & -0.13 & 0.09 \\
\hline PEDR & 26 & 0.04 & -0.21 & -0.25 \\
\hline PIAR & 14 & 0.32 & 0.07 & 0.28 \\
\hline RATE & 29 & 0.33 & 0.12 & -0.24 \\
\hline RESP & 30 & -0.15 & -0.15 & -0.27 \\
\hline SAMA & 16 & 0.33 & 0.05 & -0.43 \\
\hline SARU & 15 & -0.06 & $-0.54^{*}$ & -0.12 \\
\hline SECA & 29 & 0.26 & 0.25 & 0.10 \\
\hline SETU & 19 & -0.15 & 0.07 & -0.11 \\
\hline SOBR & 29 & -0.09 & -0.29 & -0.08 \\
\hline TESO & 15 & -0.01 & $-0.63^{*}$ & -0.18 \\
\hline VA1U & 26 & 0.34 & 0.06 & 0.07 \\
\hline VAMU & 14 & 0.19 & $-0.71 * *$ & 0.10 \\
\hline VATE & 26 & 0.18 & -0.34 & -0.15 \\
\hline
\end{tabular}

789 Values followed by $*$ and $* *$ are statistically significant at $p<0.05$ and $p<0.01$, 790 respectively. Note that data length differs between sites. 
Figure S1. Partial correlation coefficients (Spearman, $r_{s}$ ) calculated between tree-ring width and snow indices. Sites where a statistically significant correlation was found are labelled. Statistical significance of models is represented in red $(p>0.05)$ and blue $(p<$ 795 0.05) colors.

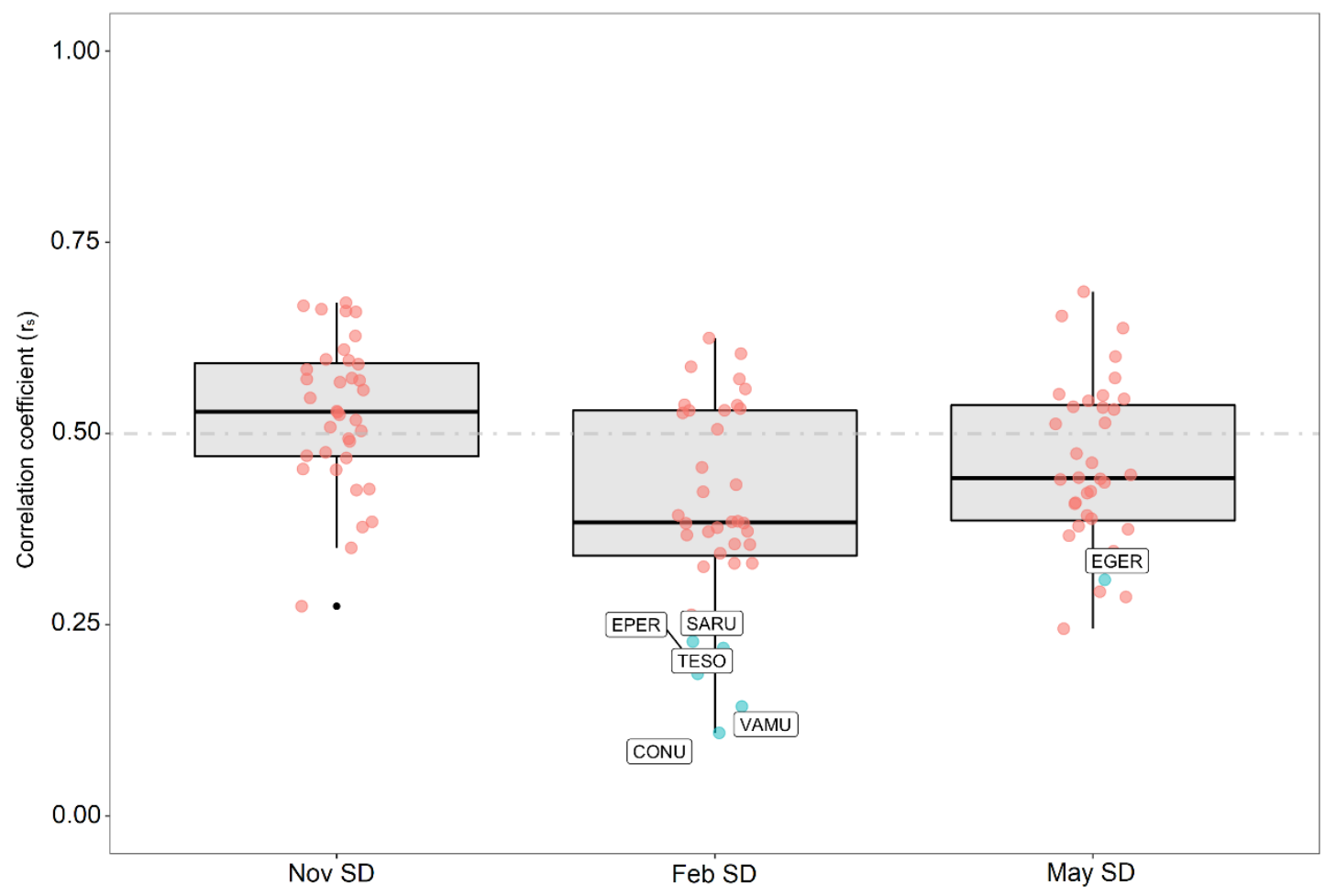


Figure S2. Latitude, longitude and elevation distribution patterns for groups of sites with the same RWI main drivers. Pre-Pyrenees (Pre-Pyr) and Iberian System (IS) locations are indicated where applicable. NA indicates sites whose selected model was null. Stars indicate sites whose selected model was statistically significant $(p<0.05)$.
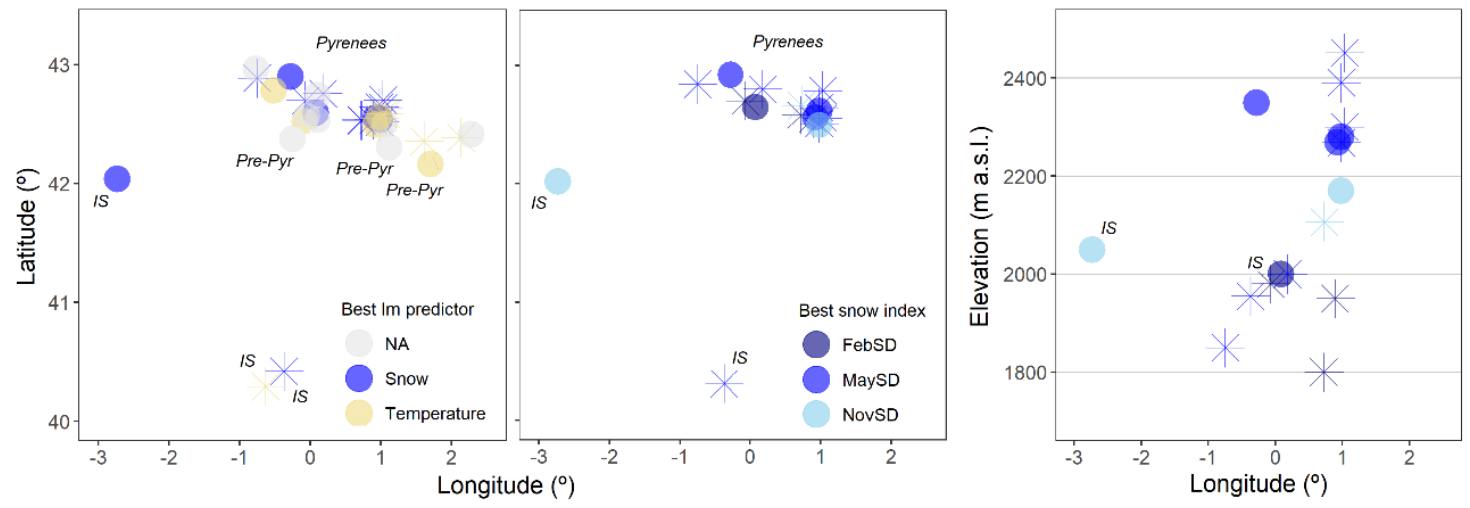
13

Figure S3. (a) Effect of geographical, nival gradients and tree influences on growth-snow partial correlations (Spearman correlations, $r_{s}$ ). The southern Iberian System sites were omitted in latitude analyses. (b) Scatterplots of statistically significant correlations ( $p<$ 0.05 ) obtained between growth-snow partial correlations and biogeographical gradients. Histograms show sites frequency of distribution along gradients.

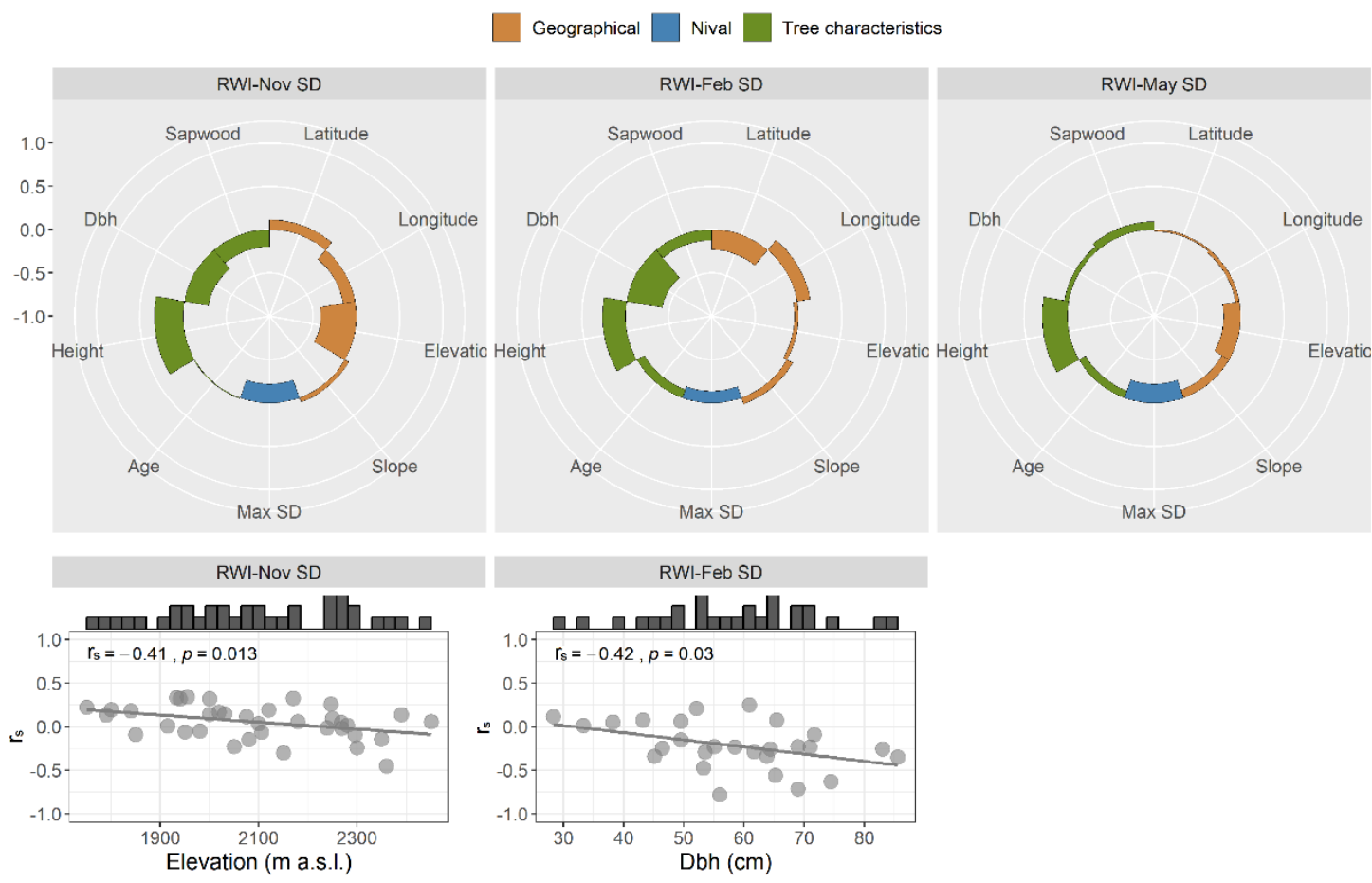


815 Figure S4. Theil-Sen's slopes (variable's units in $\mathrm{mm} \cdot$ year $^{-1}$ ) for tree-ring width (RWL) 816 and snow indices trends of selected sites from 1981 to last year with data (series' lengths 817 are shown after site codes). Statistically significant values at $p<0.05$ are represented 818 with stars. Blank values in RWL mean data is not available for these sites.
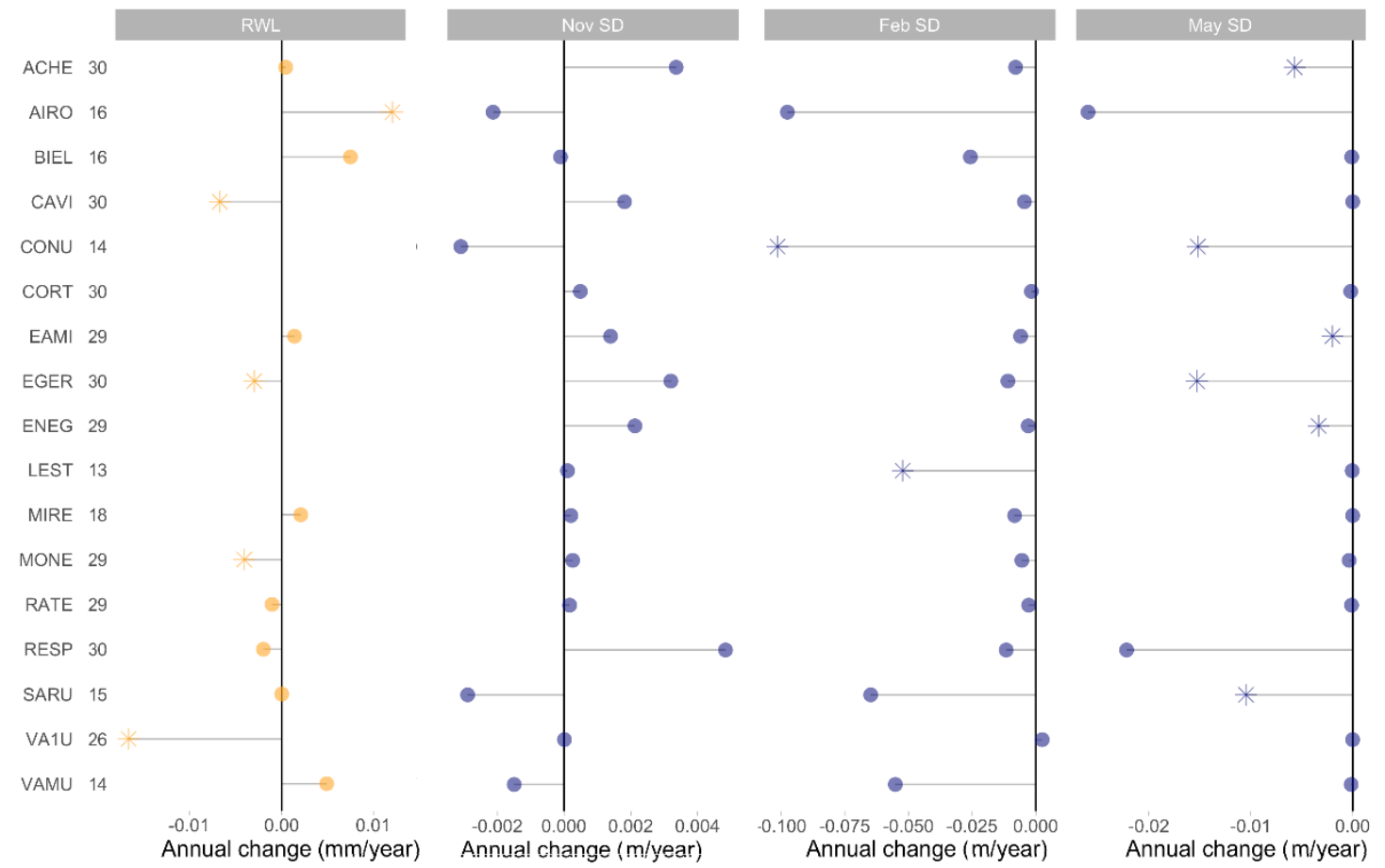